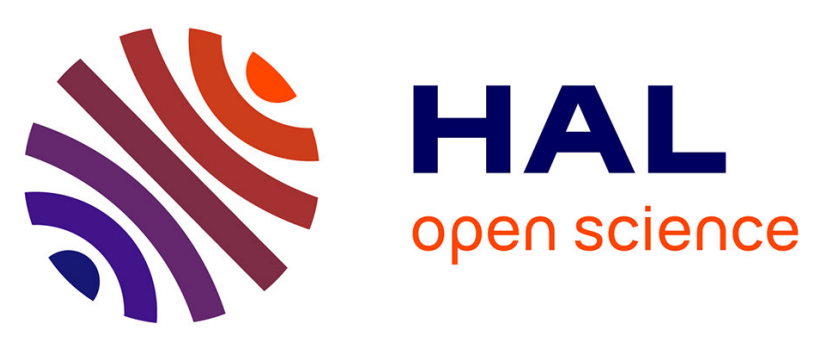

\title{
Variability of ash deposits at Piton de la Fournaise (La Reunion Island): insights into fragmentation processes at basaltic shield volcanoes
}

\author{
Simon Thivet, Lucia Gurioli, Andrea Di Muro, Julia Eychenne, Pascale
}

Besson, Jean-Marie Nedelec

\section{To cite this version:}

Simon Thivet, Lucia Gurioli, Andrea Di Muro, Julia Eychenne, Pascale Besson, et al.. Variability of ash deposits at Piton de la Fournaise (La Reunion Island): insights into fragmentation processes at basaltic shield volcanoes. Bulletin of Volcanology, 2020, 82 (63), 10.1007/s00445-020-01398-0 . hal-02930441

\section{HAL Id: hal-02930441 \\ https://hal.uca.fr/hal-02930441}

Submitted on 4 Sep 2020

HAL is a multi-disciplinary open access archive for the deposit and dissemination of scientific research documents, whether they are published or not. The documents may come from teaching and research institutions in France or abroad, or from public or private research centers.
L'archive ouverte pluridisciplinaire HAL, est destinée au dépôt et à la diffusion de documents scientifiques de niveau recherche, publiés ou non, émanant des établissements d'enseignement et de recherche français ou étrangers, des laboratoires publics ou privés. 
Variability of ash deposits at Piton de la Fournaise (La Reunion Island): insights into fragmentation processes at basaltic shield volcanoes

.

Simon Thivet ${ }^{(1)}$, Lucia Gurioli ${ }^{(1)}$, Andrea Di Muro( ${ }^{(2)}$, Julia Eychenne ${ }^{(1)}$, Pascale Besson ${ }^{(3)}$, Jean-Marie Nedelec ${ }^{(4)}$

(1) Laboratoire Magmas et Volcans, Université Clermont Auvergne - CNRS - IRD, OPGC, Campus Universitaire des Cézeaux, 6 Avenue Blaise Pascal, 63178 Aubière Cedex, France

(2) Observatoire Volcanologique du Piton de la Fournaise, Institut de Physique du Globe de Paris, Sorbonne Paris Cité, Univ. Paris Diderot, CNRS, F-97418, La Plaine des Cafres, La Réunion, Paris, France

(3) Institut de Physique du Globe (IPGP), Sorbonne Paris-Cité, CNRS UMR-7154, Univ. Paris Diderot, 1 rue Jussieu, 75238 Paris

(4) Université Clermont Auvergne, CNRS, SIGMA Clermont, ICCF, F-63000 Clermont-Ferrand, France

Author contact: simon.thivet@uca.fr

ORCID: 0000-0003-0836-6421

\section{Acknowledgments}

We thank J-L. Devidal and J-M. Hénot for their invaluable help with EPMA and SEM at LMV. We also thank the anonymous reviewers who helped us to improve the quality of the manuscript, as well as U. Kueppers and J. Taddeucci who handled the manuscript. This research was funded by ClerVolc, the French Government Laboratory of Excellence initiative $\mathrm{n}^{\circ} 425$, the EUROVOLC and I-Site programs. The online version of this article contains supplementary material, which is available to authorized users.

\section{Key-words}

Ash; basaltic; fragmentation; grain size; Piton de la Fournaise; texture 
Abstract

It is commonly accepted that effusive activity emplaces the main emitted magmatic volume in basaltic shield volcanoes. At Piton de La Fournaise (La Réunion Island, France), eruptive activity occurs mostly within the non-populated Enclos Fouqué caldera and generally does not pose any risk to the population. However, historical observations, recent monitoring data and field work on tephra deposits suggest that some eruptions have produced unusual and unexpected explosive phases. A comprehensive sampling of tephra from major historical and recent eruptions on this volcano allowed us to perform systematic componentry, grain size, chemical and morphological analyses in order to characterize the eruptive dynamics involved in these explosive basaltic eruptions. This integrative approach reveals highly variable characteristics of the studied tephra reflecting different fragmentation efficiencies and multiple associated mechanisms. Primary ductile and partially brittle fragmentation of various intensity of juvenile magma emitted during Hawaiian fountaining or mild Strombolian explosions were identified as the most common fragmentation mechanisms, in particular during the 2014-2018 dominantly effusive eruptive sequence. In parallel, we distinguished more efficient short-lived fragmentation events related to (i) plug pressurization and brittle fragmentation enhanced by syn-eruptive crystallization, (ii) magma/water interactions, (iii) rare phreatic explosions and (iv) secondary fragmentation producing fine ash during caldera collapse. We conclude that textural, geochemical and morphological analysis make it possible to identify and characterize the variability in eruptive processes, with the grain size and the componentry of the ash particles being probably the most important parameters to quantify both the efficiency and the nature of the fragmentation.

\section{Introduction and objectives}

Basaltic shield volcanoes such as Kilauea (Hawai'i Island, USA) and Piton de la Fournaise (La Réunion

Island, France; noted hereafter as PdF), are dominated by effusive activity often associated with low-energy explosive Hawaiian to Strombolian eruptions (e.g. Houghton et al. 2016; Gurioli et al. 2018; Thivet et al. 2020a, 2020b). However, field evidences and recent syn-eruptive observations at basaltic volcanoes also highlight more explosive events capable of producing fine-grained tephra, for instance at Etna (e.g. Taddeucci et al. 2002, 2004; Andronico et al. 2008; Corsaro et al. 2017; Polacci et al. 2019), Stromboli (e.g. Ripepe et al. 2005; Polacci et al. 2009; Lautze et al. 2012), Kilauea (e.g. Dvorak 1992; Mastin 1997; Neal et al. 2019) and Piton de la Fournaise (e.g. Michon et al. 2007, 2013; Staudacher et al. 2009, 2016; Ort et al. 2016). Ash-forming events, with their widespread impacts, represent a different hazard from effusive activity. Ash eruptions can impact the areas close 
to the vents where touristic activity is frequent, as well as the communities living downwind, leading to e.g. adverse health effects for humans and animals, damage to crops, infrastructure and networks disruption, water contamination (Horwell and Baxter 2006; Wilson et al. 2015). They also affect the airspace used by aviation (e.g. Song et al. 2014; Guffanti and Tupper 2015). Ash-forming events are highly unexpected in basaltic settings and the mechanisms controlling their occurrence are poorly constrained, making their forecasting challenging. To improve our ability to predict such events and mitigate their impacts, it is thus essential to understand (i) what type of fragmentation processes can produce ash (e.g. magmatic, phreatomagmatic, phreatic or volcano-tectonic), and (ii) what are the characteristics of the associated deposits (e.g. componentry, texture, grain size, morphology).

Here, we investigate a range of fragmentation mechanisms that can occur at basaltic shield volcanoes, through the comprehensive study of several tephra deposits composed of lapilli (particle diameters between 64 and $2 \mathrm{~mm}$ ) and ash $(<2 \mathrm{~mm}$, with fine ash particles $<63 \mu \mathrm{m}$, according to the Schmid 1981 nomenclature). These deposits, originated from prehistorical, historical and recent eruptions at Piton de la Fournaise (PdF), and cover a wide range of eruption styles. Based on the phenomenology of the studied events as well as the grain size, componentry, texture, morphology and chemical analysis of the tephra particles, this work brings new insights into the different eruptive mechanisms that can lead to ash-generating events at basaltic volcanoes. We used grain size and morphology analyses to constrain the fragmentation mechanisms controlling the studied events, and componentry analyses to assess the role of juvenile magma and identify the key textural features depicting the origin of both juvenile and non-juvenile components. Finally, chemical analysis provided us constraints on magma composition as well as pre- and syn-eruptive conditions.

\section{Case studies and field sampling}

PdF is the currently active volcano of the Reunion Island (Fig. 1a), situated in the Indian Ocean, approximately $750 \mathrm{~km}$ to the East of Madagascar. This volcano is one of the most active hotspot shield volcanoes in the world, with two eruptions per year on average (Peltier et al. 2018). The main and most recent $(<5000$ years) volcano-tectonic structure of PdF is the Enclos Fouqué caldera (Fig. 1b). This horseshoe-shaped depression is 250 $\mathrm{m}$ deep, $13 \mathrm{~km}$ long in the E-W axis and 6 to $8 \mathrm{~km}$ wide in the N-S axis (Michon and Saint-Ange 2008). Since the settling of permanent population on La Réunion Island (second part of the $17^{\text {th }}$ century), the volcanic activity is mainly concentrated within this structure (e.g. Villeneuve and Bachèlery 2006; Staudacher et al. 2016; Peltier et al. 2018). 

the samples studied here are located in Figure $1 \mathrm{~b}$ and listed in Figure 1c, in which some of the deposit characteristics are summarized.

Sampling of deposits from recent eruptions (part of routine sampling performed by the Observatoire Volcanologique du Piton de la Fournaise (OVPF) for each recent eruptive event, represented by green squares in Fig.1b) is either done during the eruptive activity and close to the source or just after the eruption, to be able to access strategic and very proximal deposits (Gurioli et al. 2018; Thivet et al. 2020a, 2020b). Other sampling was performed on older and key deposits representative of explosive events at PdF (orange squares in Fig. 1b). All eruptions/deposits studied here are classified by style and phenomenology (Figs. 2 and 3), which are inferred from observational data (recent eruptive events) and reviews of the literature (older events).

\subsection{Historical and recent Hawaiian fountaining activity}

Tephra produced during Hawaiian fountaining activity are the first type of samples described in this study. We collected (i) deposits emplaced between 2014 and 2018 (fountain heights of 30 to 100 m) and (ii) the Black Tephra Deposits (1450 to 1630 AD) that were emitted from Piton Chisny, a scoria cone situated outside the Enclos Fouqué caldera (Fig. 1b), likely during intense Hawaiian fountaining activity (fountain heights of hundreds of meters; Morandi et al. 2016).

(i) During the recent fissure-fed eruptions at PdF, Hawaiian fountaining phases are generally observed at the beginning of the eruptive activity, when the lava and gas flux are relatively high (Coppola et al. 2017; Thivet et al. 2020b). Figure 2a shows the sustained Hawaiian fountaining (height of around $50 \mathrm{~m}$ ) which occurred during the entire duration of the September 2016 eruption. Two months after the eruption, the whole sequence of this Hawaiian fountaining was sampled a $100 \mathrm{~m}$ from the main active vent. We also added samples from five additional eruptions that happened during the 2014-2018 period and were collected during the fountaining (with plastic sheets on the ground for February, May and July 2015 eruptions) or a few months after the eruptions, when the deposits were finally accessible, such as the June 2014 eruption (Gurioli et al. 2018). All these deposits were sampled approximately $100 \mathrm{~m}$ from the eruptive vents.

(ii) The entire stratigraphic sequence (3 m thick) of the last Piton Chisny activity (1450 to 1630 AD) called the Black Tephra Deposit (Morandi et al. 2016; Principe et al. 2016) was sampled (Fig. S1a). The two samples shown in this study (Fig. 2b) represent the initial or opening phase (tephra layer named $\mathrm{CH} 1,5 \mathrm{fo} 10 \mathrm{~cm}$ 
thick) and a relatively steady phase of long-lived lava fountaining (tephra layer named CH5, $20 \mathrm{~cm}$ thick homogeneous bed of scoria lapilli between two bomb-rich layers).

\subsection{Recent mild Strombolian and transient explosions}

The second type of samples described in this study are tephra emitted during (i) mild Strombolian eruptions (e.g. July and September 2018 eruptions) and (ii) more intense transient explosions (September 2016 eruption; Thivet et al. 2020a).

(i) During the recent fissure-fed eruptions at PdF, mild Strombolian activity (bubble bursting at the magma free surface) is generally observed a few hours or days after the beginning of the eruptive activity, when the lava and gas fluxes are progressively decreasing (Thivet et al. 2020b). This mild Strombolian activity usually occurs as discrete explosions ejecting pyroclasts to heights less than $10 \mathrm{~m}$ (Gurioli et al. 2018) and ends with decreasingly energetic spattering. The samples from the July (Fig. 2c) and September 2018 eruptions, which lasted around 1 and 47 days respectively, were collected $50 \mathrm{~m}$ from the vents, one day after the end of the Strombolian phases.

(ii) The final day of the one week long eruption of September 2016, mostly dominated by sustained lava fountaining, was characterized by a shift in activity (Thivet et al 2020a): one of the active vents turned from mild ejections and slight degassing to relatively more intense, transient bomb- and lapilli-dominated explosions (one explosion every 10 to 20 seconds producing both incandescent ejections up to $30 \mathrm{~m}$ high, yellow circle labeled 1 in Figure 2d) associated with synchronous sporadic emission of dark ash-dominated plumes (up to $300 \mathrm{~m}$ high, the ash particles being transported to proximal areas downwind, yellow circle labeled 2 in Figure 2d). Two months after the eruption, the whole sequence of deposits from the intense explosions and ash plumes was collected from a $1 \mathrm{~m}$ thick log, approximately $150 \mathrm{~m}$ from the explosive vent.

\subsection{The April 2007 explosions caused by lava flow entry in the sea}

During the caldera-forming April 2007 eruption (Piton Tremblet, source of emission only $600 \mathrm{~m}$ above sea level and only $3 \mathrm{~km}$ from the coastline; Fig. 1b), relatively high lava flux (maximum of $200 \mathrm{~m}^{3} \mathrm{~s}^{-1}$, Staudacher et al. 2009) was associated with intense Hawaiian fountaining activity (lava fountain heights up to $200 \mathrm{~m}$ ). This intense activity (from April 2 to May 1) supplied a large lava flow that rapidly reached the ocean (Michon et al. $2007,2011)$, forming a new emerged lava platform of around $5 \times 10^{5} \mathrm{~m}^{2}$ at the end of the eruption. The interaction between seawater and the hot lava generated multiple explosions, characterized by the emission of steam clouds 
rich in acidic aerosols and glass shards (laze) which are the third type of samples described in this study (Fig. 3a). The related tephra deposit (5 $\mathrm{mm}$ thick layer emplaced on a clean surface, near the Tremblet village) was collected on the day of emission (May 5), 1 kilometer from the ocean entry.

\subsection{The April 2007 caldera collapse}

Tephra can also be produced during caldera (or pit-crater) collapse events that originate from paroxysmal eruptions. Tephra deposits related to the April 2007 caldera collapse event are studied here. The intense April 2007 eruption drained the shallow magmatic system, situated $\sim 2 \mathrm{~km}$ below the summit cone (Di Muro et al. 2014). On April 5 at 8:48pm UTC, a major collapse occurred which was followed by numerous but weaker collapses until April 15 (Fontaine et al. 2014), producing a $340 \mathrm{~m}$ deep depression of a total volume of $96 \times 10^{6} \mathrm{~m}^{3}$ (Urai et al. 2007) at the summit. After the main collapse associated with ash emission (Fig. 3b), several lava flows occurred on the newly formed inner caldera walls (Staudacher et al. 2009). The emitted ash mostly dispersed within the Enclos Fouqué caldera (Staudacher et al. 2009; Michon et al. 2011, 2013). In this study, we focus on a sample collected $1.5 \mathrm{~km}$ from the source (Fig. 3b) on the western part of the Enclos Fouqué caldera on a clean solar panel surface of an OVPF station (named "La Dalle") in order to avoid any contamination. At the time of sampling the ash thickness was approximately $4 \mathrm{~mm}$.

\subsection{The March 1860 violent Strombolian eruption}

Two samples representative of the first phase of the March 1860 summit violent Strombolian eruption were collected within the summit area of PdF, and within the stratigraphic sequence (Fig. S1b) described by Michon et al. (2013). The drawing shown in Figure 3c was realized by Velain (1878) a few years after the eruption and represents the Brûlant crater which was situated on the Eastern part of the summit area where the Dolomieu caldera is situated today. After overflow then draining of an active lava lake located within the Brûlant crater (Lénat et al. 2016), several eruptive fissures opened on the flank of the volcano in February and March 1860. Summit explosions producing ash-rich plumes and block ejections were observed on March 19, 1860. The Brûlant crater was partially eroded and widened by about $300 \mathrm{~m}$. The products of this paroxysmal event were dispersed over all the PdF edifice (Villeneuve and Bachèlery 2006), but today, the deposits from this eruption are only found in the summit area of the central cone. Here, we focus on two samples (Fig. 3c) representative of the relatively fine-grained matrix (lapilli and coarse ash) of the first half of the coarse-grained (bombs, blocks and lapilli) deposit sequence (Fig. S1b), collected approximately $500 \mathrm{~m}$ from the Brûlant crater (REU131112 at the base and PF_2 at the top). 


\subsection{Prehistorical ash-rich deposits related to the formation of the Enclos Fouqué caldera}

According to Michon et al. (2016) and Ort et al. (2016), the Enclos Fouqué caldera may have formed during successive mass-sliding events towards the East. These authors have related the caldera forming events with the Bellecombe Tephra (4900 to $2250 \mathrm{BP}$ ), a thick and widespread deposit that can be found all over the PdF edifice. Ort et al. (2016) divided the stratigraphic sequence of the Bellecombe Tephra into two main units. The Lower Bellecombe Tephra (around $60 \mathrm{~cm}$ thick in a proximal outcrop named "Petite Carrière") may be related to the opening of steeply dipping fissures tapping a hydrothermal and/or magmatic system located under the newly formed Enclos Fouqué caldera. The upper Bellecombe Tephra (around $210 \mathrm{~cm}$ thick) is related to a fissure opening linked to a relative more mature hydrothermal and/or magmatic reservoir, initially emplaced westwards within the Plaine des Sables area. Two samples were collected within the lower unit and two other ones within the upper unit (Figs. 3d and S2).

\section{Laboratory methods}

\subsection{Grain size}

Grain size analyses were performed on all the studied deposits. Beforehand, the samples were dried in the oven at $90{ }^{\circ} \mathrm{C}$ during 24 to 48 hours. Manual sieving (grain size bins in wt $\%$ ) at a $1 / 2 \Phi$ scale between $-6 \Phi(64 \mathrm{~mm}$, $\Phi=-\log _{2}(\mathrm{~d}$ in $\left.\mathrm{mm})\right)$ and $5 \Phi(32 \mu \mathrm{m})$ was carried out following the procedure described in Gurioli et al. (2018). When observed, particle clusters were dismantled either by hand or using ultrasonic cleaning baths. Samples rich in fine ash were analyzed by laser diffraction using a Malvern Mastersizer 3000 (grain size bins in vol\%) in an aqueous solution, in order to quantify the Particle Size Distribution (PSD) of the sample fraction below $63 \mu \mathrm{m}$ through the application of the Mie theory (Riley et al. 2003), which allow to measure the equivalent particle diameters, regardless of the real particle shapes. Raw grain size data are available in the supplementary material (Table S1). In order to combine the two grain size methods (Eychenne et al. 2012), (i) we assumed that grain density variations below $63 \mu \mathrm{m}$ are negligible and that consequently vol\% and wt\% are equivalent (no porosity variations were observed, and the components with contrasting densities are evenly distributed though the ash fraction), and (ii) we normalized the laser data to the mass proportion of sample finer than $63 \mu \mathrm{m}$.

\subsection{Componentry, texture and chemical analysis}


For each sample, componentry analyses were performed on one specific grain size fraction, depending on the sample PSDs (cf. Figs 2 and 3), in order to distinguish juvenile from non-juvenile particles (White and Houghton 2006) based on their surface texture and morphology (angularity and roughness), porosity (high vs. low vesicle content), crystal assemblage (presence of magmatic glass and/or microlites and/or phenocrysts) and degree of alteration (fresh vs. altered and/or eroded). Textural and componentry analyses were performed (i) on the 500710 grain size fraction for coarse deposits, and (ii) on finer fractions close to PSD modes for fine deposits. At least 200 particles were counted in each fraction, using a binocular microscope (for lapilli) and Scanning Electron Microscopy (SEM) (for ash) on epoxy-impregnated polished sections. Internal textures of the samples were investigated by Backscattered Electron (BSE) imagery using both the JEOL JSM-5910 LV SEM and the Cameca SxFiveTactis Electron Probe Micro Analysis (EPMA) at LMV, with an acceleration voltage of $15 \mathrm{kV}$.

When applicable, vesicle and crystal contents were estimated based on the analysis of 20 particles on average. For the September 2016 eruption, detailed textural analysis was previously performed by Thivet et al. (2020a). Juvenile particles are characterized by different groundmass textures: in the results section, they will be described as sideromelane (glassy and transparent, with possible presence of microlites) or tachylite (fully microcrystalline and opaque) particles.

Some chemical analyses were also performed on a few samples (Table S2) by in-situ glass analyses with Cameca SxFiveTactis EPMA (acceleration voltage of $15 \mathrm{kV}$ and a current intensity of $8 \mathrm{nA}$ ) following the procedure described in Gurioli et al. (2018). For some key ash samples, mineral phases were identified by X-ray diffraction (XRD) analysis with an Empyrean diffractometer, operated at $43 \mathrm{kV}$ and $38 \mathrm{~mA}$, with the use of Ka radiation from a $\mathrm{Cu}$ anode. Inorganic Crystal Structure (ICSD) and Crystallography Open (COD) databases were used to identify the mineral phases. The ash samples were analyzed from 2 to 50 degrees $2 \theta$, with a step width of 0.02 degrees $2 \theta$ and two second counting time for each step.

2D ash morphology was quantified using the automated Malvern Morpho-Grainsizer Morphologi G3 following the method developed by Leibrandt and Le Pennec (2015) and adapted by Thivet et al. (2020a). Before the analysis, specific grain size fractions were selected within $1 / 4 \Phi$ bins from $0.75 \Phi(600 \mu \mathrm{m})$ to $4 \Phi(32 \mu \mathrm{m})$, depending on the deposit grain size. The narrow $1 / 4 \Phi$ range favors the grain size homogeneity for the morphological analysis. When possible, we performed the morphology measurements on similar grain size fractions from one deposit to another to allow data comparison without grain size bias. Several grain size fractions 
were also analyzed within the same sample to check the effects of the grain size on the morphology. Apparent Projected Shape of Ash (APASH) was automatically measured by the instrument, via several morphology and roughness parameters, on a high number of ash particles dispersed on a glass slide. Front lightning with various magnifications (from $2.5 \mathrm{x}$ to $20 \mathrm{x}$ ) was used depending on the particle sizes. In this study we focused on two roughness parameters, namely the solidity (SLD) and the convexity (CVX), which represent morphological (particle scale) and textural (smaller scale) roughness of the particles, respectively. The study of Liu et al. (2015) gives a global overview on how to interpret the different shape parameters, especially SLD and CVX, and how to link these with magmatic textures. For instance, a perfect round or square particle has a SLD and CVX value of 1. On the other hand, SLD and CVX decrease as soon as shape irregularities appear. We also focused on one morphological parameter, the aspect ratio (AR), which represents the elongation of the particles. These three parameters are defined as follow (Leibrandt and Le Pennec 2015): SLD $=\mathrm{A} / \mathrm{A}_{\mathrm{CH}}, \mathrm{CVX}=\mathrm{P}_{\mathrm{CH}} / \mathrm{P}$ and $\mathrm{AR}=\mathrm{W}_{\mathrm{b}} / \mathrm{L}_{\mathrm{b}}$ where $\mathrm{A}$ is the particle area $\left(\mu \mathrm{m}^{2}\right), \mathrm{A}_{\mathrm{CH}}$ is the area $\left(\mu \mathrm{m}^{2}\right)$ of the convex-hull (smallest convex polygon that contains all the pixels of the particle), $\mathrm{P}$ is the particle perimeter $(\mu \mathrm{m}), \mathrm{P}_{\mathrm{CH}}$ the convex-hull perimeter $(\mu \mathrm{m}), \mathrm{W}_{\mathrm{b}}$ the minor axis and $\mathrm{L}_{\mathrm{b}}$ the major axis of the particle. In specific cases and in order to distinguish between angular and spherical shapes, we also studied the sphericity (SPH, also known as HS circularity or Shape Factor) which relates the perimeter to the area of the particles (Riley et al. 2003; Leibrandt and Le Pennec 2015): $\mathrm{SPH}=(4 \pi \mathrm{A}) /\left(\mathrm{P}^{2}\right)$. SLD, CVX, AR and SPH are dimensionless parameters varying between 0 and 1 . The raw data for each parameter are shown in Table S3. These data were previously filtered to remove artificial particle clusters form the database (several particles that touch each other): a manual but rigorous verification was systematically performed on each automatically identified particle.

\section{Results on the deposits characterization}

\subsection{Tephra deposits from Hawaiian fountaining activity}

\subsubsection{Recent investigated eruptions (2014 to 2018)}

The deposits are mostly composed of lapilli with a moderate ash content between 10 and $58 \mathrm{wt} \%$, but none of them contain detectable fine ash. All these Hawaiian deposits are only composed of juvenile particles, characterized by vesicle-rich and microlite-poor sideromelane particles (golden pumice and fluidal scoria pyroclasts). Thivet et al. (2020a) presents detailed textural analysis within the 500-710 $\mu \mathrm{m}$ size fraction on the 
September 2016 Hawaiian fountain deposits, showing that these ash particles are composed of $42 \mathrm{vol} \%$ of vesicles and only 1 vol\% of microlites. Microlites are mainly plagioclase and scarce clinopyroxene. Micro-phenocrysts of olivine (Fig. 2a), plagioclase or clinopyroxene can also occur depending on the eruptions. Vesicles can be either round and isolated within the glassy matrix or highly elongated. The PSDs of these samples (Figs. 4a) are unimodal with modes between 2 and $8 \mathrm{~mm}$ depending on the eruptions. The morphology of these particles, measured within the 250-300 grain size fraction (Fig. 5a), are relatively heterogeneous (CVX between 0.61 and 1.00, SLD between 0.39 and 1.00, and AR values between 0.10 and 1.00), reflecting the systematic presence of round droplets (CVX, SLD and AR values near 1), fluidal and poly-lobed fragments, as well as elongated particles with sometimes Pele's hairs (lower CVX, SLD and AR values). Note that the July 2015 sample was measured within a larger grain size fraction $(500$ to $600 \mu \mathrm{m})$ but no significant differences are observed in terms of shape except that elongated particles are slightly more abundant in this fraction (lowest AR median (0.65) measured in this study). Depending on the samples, SPH medians span a range from 0.49 to 0.65 (Table S3).

\subsubsection{The Black Tephra deposits of Piton Chisny (1450 to 1630 AD)}

The initial phase of the sampled sequence (labelled CH1 in Fig. 2b), is composed of juvenile lapilli (39 $\%)$ and juvenile ash (56 wt $\%$ of coarse ash and $5 \mathrm{wt} \%$ of fine ash). This ash is either composed of sideromelane or tachylite particles (Fig. 2b) showing heterogeneous magmatic textures that range from vesicle-rich and crystalpoor to vesicle-poor and crystal-rich matrixes. The PSD of this sample is multimodal (Fig. 4b) with two main modes between 11.3 and $16 \mathrm{~mm}$ (only composed of sideromelane lapilli, golden pumice and fluidal scoria) as well as between 180 and $250 \mu \mathrm{m}$ (mostly composed of tachylite ash with scarce sideromelane ash). Interestingly, the content of tachylite particles within the deposit increases towards the fine grain sizes, from $6 \%$ (2-2.8 mm), to 10 $\%(1.4-2 \mathrm{~mm})$, to $11 \%(1-1.4 \mathrm{~mm})$ to $19 \%(500-710 \mu \mathrm{m})$ to finally $83 \%(180-250 \mu \mathrm{m})$. Scarce individual olivine phenocrysts were also observed (Fig. 2b). Looking at the BSE images it is clear that the tachylite particles show relatively different shapes with rougher surfaces than sideromelane ones. However, no clear differences are observed in term of morphology (Fig. 5b) compared to the 2014-2018 Hawaiian ash particles because the tachylite particles within the $\mathrm{CH} 1$ sample are dispersed with the sideromelane particles which have more heterogeneous shapes.

This CH1 layer is overlain by a sequence of about $3 \mathrm{~m}$ thick coarser layers (separated by several bombrich layers) which have very similar PSD (Fig. S1a). The labelled sample CH5 (Fig. 2b) is globally representative of these subsequent deposits which are only composed of juvenile sideromelane particles (golden pumice and 
fluidal scoria pyroclasts), with only 6 wt $\%$ content of ash and with no detectable fine ash. Thus, this deposit is relatively different from the opening phase. In spite of its significant thickness and large dispersion (Morandi et al., 2016), the Chisny lapilli deposit is very similar to the recent and weak Hawaiian fountaining deposits described earlier in this section, with a unimodal PSD, the grain size mode being between 5.6 and $8 \mathrm{~mm}$ (Fig. 4b). The ash morphologies are also quite similar to the recent ash produced during weak Hawaiian fountaining (Fig. 5b).

\subsection{Tephra deposits from recent mild Strombolian and transient explosions}

\subsubsection{The July and September 2018 mild Strombolian activities}

The deposits collected from mild Strombolian activities during July 2018 and September 2018 (Fig. 2c) eruptions are mostly composed of lapilli with a very low ash content (5 to $6 \mathrm{wt} \%)$ and with no detectable fine ash. These deposits are only composed of juvenile sideromelane particles. Textural observations performed on the 500$710 \mu \mathrm{m}$ grain size fraction highlights an increase in the microlite content (20 to $30 \mathrm{vol} \%$ ) and a decrease in the vesicle content (10 to $20 \mathrm{vol} \%$ ) compared to the Hawaiian particles. Most of the vesicles are round, while some vesicles are larger and characterized by irregular shapes. The microlite populations are composed by plagioclase, clinopyroxene and very scarce olivine, in order of abundance. The PSD of these two 2018 samples are unimodal, relatively similar to the Hawaiian samples (apart for the ash content), with grain size modes between 5.6 and 8 mm (Fig. 3c). Ash morphology measurements were performed on the 250-300 $\mu \mathrm{m}$ grain size fraction and the particle CVXs, SLDs and ARs are respectively higher than 0.68, 0.58 and 0.19 (Fig. 5c), reflecting fluidal shapes associated with spiny, rough particles.

\subsubsection{The specific case of the September 2016 transient explosions}

Deposits from the September 2016 transient explosions contain two different type of juvenile particle components, respectively sideromelane (REU161211_10, labelled 1 in Fig. 2b) and tachylite ones (REU161211_6, labelled 2 in Fig. 2b), as already described in Thivet et al. (2020a). The deposit formed by the sideromelane component is a typical coarse-grained Strombolian deposit composed of only $8 \mathrm{wt} \%$ of ash, while the deposit related to the tachylite component is composed of $97 \mathrm{wt} \%$ of coarse ash. None of these deposits contain detectable fine ash. The sideromelane ash textures have similar textures than the ones described in the Mild Strombolian section (labeled 1 in Fig. 2d). Thivet et al. (2020a) already performed precise textural analysis on these samples, showing a low content of vesicles (13 vol\%) and microlites (17 vol\%) of plagioclase, clinopyroxene and olivine (within the 500-710 $\mu \mathrm{m}$ grain size fraction). Vesicles are sometimes deformed. The tachylite ash particles (labeled 
2 in Fig. 2d) are characterized by a relatively low content of vesicles (10 vol\%), and a fully crystallized matrix

310 (100 vol\%) composed of normally zoned microlites of plagioclase and clinopyroxene associated with olivine microlites and Fe-Ti rich micro-oxides (still within the 500-710 $\mu \mathrm{m}$ grain size fraction). Sideromelane and tachylite textures are sometimes mingled together (mingled clasts) even at microscopic scale. XRD analyses discard the presence of any hydrothermal-induced mineral phases on both sideromelane and tachylite deposits. PSD of the sideromelane deposit shows a similar pattern as the mild Strombolian samples previously described, although with a coarser grain size mode between 22.6 and $32 \mathrm{~mm}$. In contrast, the PSD of the fine-grained tachylite deposit is unimodal with a mode between 500 and $710 \mu \mathrm{m}$ (Fig. 4c). Ash morphology, performed on the 250-300 $\mu \mathrm{m}$ grain size fraction (Fig. 5c), show that the sideromelane ash has very similar morphology signatures as the mild Strombolian samples. However, the tachylite ash particles do not have smooth surfaces anymore (CVX and SLD values $<0.95$ ) and are rougher both in terms of SLD (particle scale) and CVX (micron scale), than the sideromelane ash particles, with no evidence of significant elongation features (AR values > 0.40 and a slightly higher SPH median of 0.69 compared to the Hawaiian and Strombolian particles).

\subsection{Tephra deposits from the explosions caused by the April 2007 lava flow entry in the sea}

The hydromagmatic deposit from the April 2007 lava flow entry is only composed of juvenile coarse ash among with very scarce fine ash $(1 \mathrm{wt} \%)$. Particles are dense and glassy, and looking at the 500-710 $\mu \mathrm{m}$ grain size fraction they are characterized by relatively low vesicle content (less than 20 vol\%), very low microlite content (less than $10 \mathrm{vol} \%$ ) and variable but relatively high olivine phenocryst content (Fig. 3a), in agreement with the fragmentation of the olivine-rich lava from whom they are originated (Staudacher et al. 2009; Di Muro et al. 2014). These olivine phenocrysts (both free crystals and composite particles of liquid and phenocrysts) are highly fractured. Very scarce particles have a dendritic texture (Fig. 3a). The PSD of this deposit is relatively fine-grained and unimodal, mode being between 500 and $710 \mu \mathrm{m}$ (Fig. 4d). Morphology of these particles (performed on many grain size fractions, Fig. 5d) is highly distinctive with respect to Hawaiian and Strombolian deposits mostly because these particles are relatively elongated with extreme AR values down to 0.03 , reflecting the presence of abundant glassy Limu o Pele shards (following the nomenclature described in Maicher and White 2001). These kind of shards show elongation, deformation and folded features, with fluidal shapes and fractured surfaces. No significant morphology differences are observed depending on the different grains size fractions measured.

\subsection{Tephra deposits from the April 2007 caldera collapse}



of ash particles with a large amount of fine ash $(87 \mathrm{wt} \%)$, the largest in our sample set. This ash deposit contains particle clusters forming irregular-shaped aggregates, composed of both coarse and fine grains and showing random particle grain size arrangement (Fig. 3b). Most of the particles are considered as non-juvenile (> $99 \mathrm{wt} \%$ ). These non-juvenile particles are sometimes altered and systematically characterized by the absence of vesicles, by fully crystallized gabbroic textures (assemblage of plagioclase, pyroxene, olivine and oxides), with also the presence of individual and fractured crystal-free particles, which are not coated with magmatic glass. However, very scarce particles $(<1 \mathrm{wt} \%)$ are considered as juvenile. They are either represented by individual glass fragments with a moderate content in $\mathrm{MgO}(4.9 \pm 0.1 \mathrm{wt} \%)$ and in $\mathrm{K}_{2} \mathrm{O}(1.3 \pm 0.1 \mathrm{wt} \%)$, or by tachylite particles with no clear evidence of significant alteration. We also note that a small amount of Pele's hairs is dispersed in this deposit. These Pele's hairs have a bimodal composition (Table S2) with magnesian (MgO: $8.1 \pm 0.3 \mathrm{wt} \%$ ) and evolved, low $\mathrm{MgO}(2.9 \pm 0.8 \mathrm{wt} \%)$ melts.

XRD analysis performed on the April 2007 caldera collapse deposit confirmed the presence of plagioclase, clinopyroxene and olivine crystals (observed in the gabbro fragments) and also suggest the presence of both montmorillonite (clay) and hematite phases. The PSD of this sample is unimodal with a mode between 15 and $8 \mu \mathrm{m}$ (Fig. 4e). Ash morphology performed on this sample and on three different grain sizes (Fig. 5e) show very different results from the other samples: most of the CVX and SLD values range between 0.90 and 1.00 reflecting the presence of both fine grained, blocky and large, round particles without significant rough surface features (Fig. 3b). Looking at the relatively high AR values (median between 0.70 and 0.80 ) they suggest that these particles are mostly blocky without elongation features. Depending on the grain size, slight differences on the averaged SPH are observed (Table S3): the coarsest analyzed grain size bins (150-180 mm and 63-75 mm) show the highest SPH values measured in this study ( 0.83 and 0.84 respectively), while the finest analyzed grain size (32-43 mm) show slightly lower values (0.79). These SPH values are in accordance with the SEM observations: in this sample, the ash particles tend to be more angular towards the finer grain sizes.

\subsection{Tephra deposits from the March 1860 violent Strombolian eruption}

The sample collected at the base of the deposit (REU131112, Fig. S1b) is composed of lapilli (44 wt\%) and ash (55 wt $\%$ of coarse ash and $1 \mathrm{wt} \%$ of fine ash). Within the $500-710 \mu \mathrm{m}$ grain size fraction, juvenile particles represent only $2 \%$ which are characterized by non-altered, more or less vesiculated glassy matrix. The nonjuvenile particles ( $98 \%$ ) are dense, characterized by fully crystallized matrix (Fig. 3c). The size of the crystals of 
these particles vary from a few tens of microns (microlite-rich and altered or oxidized particles, thus considered as recycled non-juvenile tachylite particles) to several hundreds of microns (fully crystallized micro-gabbro texture, thus considered as non-juvenile intrusive fragmented material). Micro-gabbro textures are characterized by larger crystal in terms of length and width (plagioclase, clinopyroxene and olivine) than in the juvenile or recycled particles (microlites and micro-phenocrysts sometimes associated with unaltered glass). Scarce olivine individual crystals are counted within the non-juvenile particles, because they are not wetted with fresh glass. The PSD of this sample is unimodal with a grain size mode between 1.4 and $2 \mathrm{~mm}$ (Fig. 4f), finer than that of Hawaiian and Strombolian deposits, but coarser than that of hydromagmatic ash from the April 2007 lava flow entry. Within the 355-500 $\mu \mathrm{m}$ grain size fraction, most of the particles are non-juvenile (89\%). All the particles of this layer show the same textures as in the REU131112 sample. XRD analysis performed on the PF_2 samples suggests the presence of plagioclase, clinopyroxene, olivine (already observed with the SEM) and hematite phases. The PSD of this sample is unimodal with a grain size mode finer than the previous sample, between 355 and $500 \mu \mathrm{m}$ (Fig. 4f).

Despite a small difference on the measured grain size fractions, the particle morphology of the two samples representative of this eruption are very similar to each other (Fig. 5f): CVX and SLD medians for both samples are around 0.95 and AR values are relatively high with medians at 0.78 , mostly reflecting gabbroic or altered particles with rough and blocky shapes. The median values of SPH (Table S3) measured on both samples are relatively high $(0.73$ and 0.75$)$ reflecting the presence of blocky non-juvenile particles without any significant irregularity features, in accordance with the previous observations.

\subsection{The Bellecombe Tephra deposits (4900 to $2250 \mathrm{BP}$ )} BE_BASE_2, Fig. S2) have similar and very high ash content (between 85 and 91 wt\%), with however slightly different fine ash content ( 32 and $11 \mathrm{wt} \%$ respectively). Based on the componentry analysis performed on the 250$355 \mu \mathrm{m}$ grain size fraction of the BE_BASE_1 sample (Fig. 3d), we suggest that this ash fraction is only composed of non-juvenile particles either characterized by altered glassy clasts (40\%), micro-gabbro (40\%), and individual olivine crystal fragments (20\%). We consider that the alteration observed on these particles is representative of the fragmentation conditions but the alteration may also have occurred after the tephra deposition regarding the relatively old age of the eruption, and this is the limit of the componentry analysis. Grain size mode of these two 
samples (Fig. 4g) are skewed toward relatively fine grain size fractions (between 31 and $63 \mu \mathrm{m}$ for the BE_BASE_1 sample and between 180 and $250 \mu \mathrm{m}$ for the BE_BASE_2 sample).

Samples collected within the primary (non-reworked) layers of the Upper Bellecombe Tephra (BE_TOP_1 and BE_TOP_2, Fig. S2) have lower ash content than the Lower Bellecombe Tephra samples (between 47 and 59 wt\%) with also lower fine ash content (between 2 and 3 wt $\%$ ). Similarly to the Lower Bellecombe Tephra samples, componentry performed on the $250-355 \mu \mathrm{m}$ grain size fraction of the BE_TOP_1 samples suggest that this ash fraction is only composed of non-juvenile particles, consisting in the same types of fragments of the BE_BASE_1 sample (Fig. 3d). Irregular-shaped particle clusters (following the Brown et al. 2012 nomenclature) are much more abundant than in the layers of the Lower Bellecombe Tephra and are characterized by a random grain size organization. Grain size mode of these two samples are skewed toward coarser grain size fraction (Fig. 4g) than the Lower Bellecombe Tephra samples (two modes between 8 and $11.3 \mathrm{~cm}$ as well as between 1.4 and $2.8 \mathrm{~cm}$ for the BE_TOP_1 sample and one mode between 1.4 and $2 \mathrm{~cm}$ for the BE_TOP_2 sample). In addition to the plagioclase, clinopyroxene and olivine phases, XRD analysis performed on both Lower and Upper Bellecombe Tephra suggest the presence of montmorillonite and quartz.

Ash morphology measurements performed on the four Bellecombe samples show quite similar patterns (Fig. 5 g) reflecting the presence of three different types of non-juvenile particles, namely the glassy altered ones which have fluidal to spiny shapes (especially for the Lower Tephra samples), as well as the individual crystalfree and micro-gabbro blocky fragments. Similarly to the March 1860 analyzed deposits, the average values of SPH (Table S3) measured on the four Bellecombe samples are relatively high (between 0.71 and 0.77 ) reflecting the presence of blocky, non-juvenile particles without any significant irregularity features.

\section{Discussion on the fragmentation mechanism variability}

In this study, we chose to study a wide range of tephra deposits (in terms of texture, morphology, grain size, and chemistry) in order to depict the variability of ash-forming events occurring at a basaltic shield volcano. As a consequence, we could only analyze a limited number of samples for each selected deposit. In order to work on thick deposits and visualize the entire stratigraphy representing the whole of the eruptive sequences, we systematically collected samples from proximal locations (50 to $1500 \mathrm{~m}$ from source). We are confident that this sampling strategy is appropriate for pursuing the objectives of this study, i.e. deciphering the processes of ash 
formation and describing the characteristics of the resulting particles. One sample is representative enough of the weakest, very short-lived explosions, which are limited in time (very brief) and space (poorly dispersed). The tephra deposits from older eruptions (March 1860, Piton Chisny, and Bellecombe) are relatively heterogeneous in terms of lithology and grain size (Figs. S1 and S2), but we identified the best outcrops representing the whole sequence of events, and carefully selected specific layers representative of the main eruptive phases of each eruption, based on our observations and the literature when available.

All the samples described in this study were affected by transport-dependent processes, which normally limit the comparison between samples collected at different distances from vent, especially when dealing with PSD. However, all the samples were collected at similar distances close to their sources (most of them less than 500 meters from source, Fig. 1c), thus effects of transport processes are negligible. Only the two 2007 samples were collected $1.5 \mathrm{~km}$ from source, because we favored clean sampling surfaces to avoid mixing between the multiple ash-sources observed during the 2007 eruption. More proximal samples were available (300 meters from source) and show similar PSDs to the more distal samples selected here, which demonstrates that the variations in PSDs can be confidently interpreted in terms of differences in fragmentation efficiency.

\subsection{Variability and origin of the eruptive dynamics}

\subsubsection{Hawaiian fountaining: breakup of vesicle-rich and crystal-poor juvenile magmas}

The investigated Hawaiian fountaining events at PdF produced sustained lava fountains with heights ranging from 30 to $100 \mathrm{~m}$ (Fig. 2a). The associated deposits are characterized by lapilli-dominated (Fig. 4a), vesicle-rich, and crystal-poor juvenile pyroclasts (Fig. 2a). Despite their homogenous textures, the emitted ash particles show a large range in morphology (Fig. 5a and Table S3). The presence of round droplets and elongated particles with smooth surfaces, highlight that magma fragmentation occurred at low viscosity and that the final pyroclast shape was acquired in the air post-fragmentation just before quenching. Round liquid droplets formed due to surface tension while the high projection velocity shaped the elongated filaments (Shimozuru 1994). Particles with poly-lobed contours show that magma fragmentation was also controlled by the numerous thin bubble walls that rapidly quenched and broke up. The low magma viscosity interpretation is in agreement with a previous estimation $\left(10^{2} \mathrm{~Pa} \mathrm{~s}\right)$ based on a three-phase viscosity model (vesicle and crystal content as well as melt composition) performed on the magmas from the Hawaiian-style activity of the September 2016 eruption at PdF (Thivet et al. 2020a). Moreover, most of the studied deposits contain Pele's hairs of different size with various content in deformed vesicles, representative of low viscosity magmas exhibiting different quenching rates and 
residence time in the hot lava fountain (Porritt et al. 2012; Mangan et al. 2014; Cannata et al. 2019). The relatively high vesicle number density $\left(\mathrm{N}_{\mathrm{V}}\right)$ and low microlite number density $\left(\mathrm{N}_{\mathrm{C}}\right)$ measured in the ash, especially during the September 2016 event (Thivet et al. 2020a), reflect hot magmatic liquids exhibiting high decompression rates (Toramaru 2006) and low syn-eruptive outgassing and crystallization (Toramaru et al. 2008). This is consistent with closed system, low-viscosity magma degassing during Hawaiian fountaining that has been related to intense bubbly flow (Cashman and Scheu 2015) and even annular flow dynamics within the volcanic conduit (e.g. Jaupart and Vergniolle 1988, 1989; Houghton and Gonnerman 2008). Similar textures are found in lava fountain deposits from other volcanoes as Etna (e.g. Polacci et al. 2006; Andronico et al. 2008; Andronico and Corsaro 2011) and Kilauea (e.g. Stovall et al. 2011, 2012; Parcheta et al. 2013; Cannata et al. 2019) but the heights and the intensity of the lava fountains are generally higher in these latter volcanoes compared to PdF. Moreover, Etna eruptions stand out from the typical Hawaiian activity for the recurrent formation of ash-rich eruptive columns up to several kilometers high (e.g. Andronico et al. 2015; Corsaro et al. 2017; Potter et al. 2019).

The textural variability of juvenile tephra from a same eruption is well-known in a basaltic context (e.g. Pioli et al. 2014; Gurioli et al. 2014; Polacci et al. 2019). This is the case of the deposits from the opening phase of Piton Chisny historical activity (CH1 sample) which is much richer in ash particles. Interestingly, the smaller grains of these deposits are mostly composed of crystal-rich and vesicle-poor sideromelane as well as tachylite particles, while the coarser grains mostly show crystal-poor and vesicle-rich sideromelane textures (Fig. 2b). The texture variation from sideromelane to tachylite can be interpreted as syn-eruptive degassing and crystallization within the eruptive conduit, as demonstrated at other basaltic systems (e.g. Taddeucci et al. 2002; Sable et al. 2006; D’Oriano et al. 2014; Polacci et al. 2019) and in experiments (e.g. Simakin et al. 1999; Applegarth et al. 2013; Arzilli et al. 2015). This shows that the portion of viscous magma exhibits the highest degree of fragmentation. We thus suggest that syn-eruptive degassing-driven crystallization of the Piton Chisny opening phase drastically increased the magma viscosity and enhanced magma fragmentation (Arzilli et al. 2019), which was probably more brittle than the Hawaiian counterpart. The presence of both vesicle-rich (high $\mathrm{N}_{\mathrm{V}}$ reflecting high decompression rates) and crystal-rich particles (high $\mathrm{N}_{\mathrm{C}}$ reflecting an increase in magma viscosity in the conduit) in the $\mathrm{CH} 1$ sample, provides additional evidence of enhanced magma fragmentation (Cimarelli et al. 2010; Cashman and Scheu 2015). Syn-eruptive crystallization may be facilitated by a long magma residence time during initiation and propagation of the eruptive conduit from a deep reservoir (Morandi et al. 2016) to the surface. After the opening phase and the formation of the eruptive conduit, the magma residence time in the conduit decreased resulting in typical lava fountain activity (CH5 sample). 


\subsubsection{Strombolian explosions: towards brittle fragmentation of relatively degassed juvenile magmas}

At PdF, mild Strombolian explosions occur towards the end of dyke eruptions and temporally follow the fountaining activity, when the lava fluxes are decreasing (Thivet et al. 2020b). Mild Strombolian activity generally focuses in a single vent/cone producing weak projections, not exceeding heights of a few tens of meters (Fig. 2c). Bubble explosions at the magma free surface, within generally well-constructed scoria cones, are relatively weak but temporally close (only a few seconds between each burst, similar to the mild-Strombolian activity described by Spina et al. 2017 at Etna volcano) compared to the typical regime at Stromboli (e.g. Chouet 2003; Ripepe et al. 2001; Harris and Ripepe 2007). The associated deposits are characterized by bomb and lapilli-dominated (Fig. 4c) juvenile pyroclasts with crystal-rich sideromelane textures. A decrease in porosity and an increase in microcrystallinity (Fig. 2c) are thus observed compared to the magma emitted during the lava fountain activity (golden and fluidal material). The decrease of $\mathrm{N}_{\mathrm{V}}$ and the increase of $\mathrm{N}_{\mathrm{C}}$ as well as some evidence of vesicle coalescence (occurrence of a second, irregularly-shaped vesicle population of larger size) within the sideromelane ash particles suggest that the mild Strombolian dynamics, typically active during slug flow (e;g. Jaupart and Vergniolle 1988, 1989; Houghton and Gonnerman 2008; Chouet et al. 2003; Oppenheimer et al. 2020), is related to lower decompression rates associated with higher syn-eruptive degassing and crystallization (Thivet et al. 2020b). It also marks the transition from closed to open system degassing. Sideromelane particle shapes from bubble explosions (Fig. 5c) differ from the clast shapes produced by the Hawaiian fountaining activity. First, the absence of significant post-fragmentation features as well as the absence of Pele's hairs and tears, suggest that the relatively low temperature and high viscosity do not allow patricles to deform during and after fragmentation. Moreover, the rough and spiny shapes of the Strombolian particles may reflect primary brittle fragmentation behavior, mostly due to lower magmatic temperatures and higher crystal contents (both cooling and degassing of the magma in the conduit enhanced by a longer residence time compared to the Hawaiian fountaining dynamics), resulting in an increase in viscosity ( $10^{3} \mathrm{~Pa}$ s, calculated value for the sideromelane September 2016 magma, Thivet et al. 2020a).

We conclude that the magmas emitted during these mild Strombolian explosions have slightly higher viscosities than their Hawaiian counterparts. However, vesicles are well coupled with the melt in the Hawaiian regime, but open degassing system and volatile percolation occur in the Strombolian regime, which drastically decrease the fragmentation efficiency. This results in the lowest ash content of the investigated dynamics at PdF.

Similarly to the textural variations observed between the $\mathrm{CH} 1$ and $\mathrm{CH} 5$ samples, we observed an evolution from sideromelane to tachylite particles emitted during the specific case of the September 2016 transient 
explosions. The texture and associated features of the tachylite ash emitted during these explosions, already quantified in a previous study, highlight that these juvenile particles are totally crystallized and degassed $(0 \mathrm{wt} \%$ of dissolved $\mathrm{H}_{2} \mathrm{O}, 10 \mathrm{vol} \%$ of vesicles, Thivet et al. 2020a). In-situ chemical and textural analysis, as well as syneruptive observations, suggest that the emitted ash originated from sub-surface degassing and crystallization of the initial magma (Thivet et al. 2020a). The degassed/cooled magma formed a rheological and impermeable layer, which played the role of a plug, within one of the two active vents. The ascent of still partially undegassed magma (sideromelane) fragmented the plug layer composed of tachylite magma (brittle fragmentation by plug pressurization/decompression). Note that, XRD analysis discard the presence of any hydrothermal-induced mineral phases that can be related to involvement of hydrothermal fluids or fragmentation of surrounding rocks (phreatomagmatic mechanisms). Brittle fragmentation is also evidenced by the ash morphologies (Fig. 5c). CVX, SLD, AR and SPH values are skewed toward higher median values for tachylite ash than sideromelane particles, reflecting typical tachylite textures with rough surfaces and no significant particle deformation. Moreover, ash particles with CVX, SLD and AR values of 1.00 are not observed, suggesting that magma viscosity is too high to produce round droplets like it was the case in the golden ash component.

\subsubsection{Lava-ocean interactions provoking hydrovolcanic explosions}

When a lava flow enters a body of water like the sea at relatively high fluxes $\left(>4 \mathrm{~m}^{3} \mathrm{~s}^{-1}\right)$, hydrovolcanic explosions producing laze can occur like it was the case at Kilauea volcano (Mattox and Mangan 1997; Neal et al. 2019), and at PdF during the April 2007 eruption (Fig. 3a), which was fed by a lava peak flux of at least $200 \mathrm{~m}^{3} \mathrm{~s}^{-}$

${ }^{1}$ (Staudacher et al. 2009). Laze is characterized by the emission of steam clouds highly concentrated in hydrochloric acid and glass shards (Carlos et al. 2018). According to Mattox and Mangan (1997), the ideal water/magma ratio to provoke littoral explosions is around 0.15 and an open mixing of lava and seawater (when the mouth of several lava tubes or lava channels are exposed to sea waves) is the most efficient situation to produce unconsolidated deposits of glassy, dense lava fragments. The particles formed during the 2007 seawater-provoked explosions were immediately quenched and show a glassy matrix with rare microlites (Limu o Pele glass shards) and more abundant phenocrysts of olivine, already present within the lava flow itself, as it was described in Hawaii (Potuzak et al. 2008). The dendritic texture observed in very scarce particles (Fig. 3a) suggest that some of the fragmented material experienced not instantaneous but fast quenching. The particles show typical fractured features on their surfaces and inside the matrix glass. Concentric fractures are often observed around the olivine phenocrysts (Fig. 3a). We suggest that the intensity of the sudden fragmentation, the almost instantaneous quenching as well as the thermic contraction are the main cause of these brittle features (Büttner et al. 1999; 
Zimanowski et al. 2015). Extreme AR values (down to 0.05) reflect the formation of typical elongated glassy shards particles (Fig. 5d) during these hydrovolcanic explosions.

\subsubsection{The April 2007 caldera collapse: phreatic (or phreatomagmatic) explosions associated with secondary}

\section{fault-shear fragmentation}

The deposit associated with the ash emission during the April 2007 caldera collapse (Figs. 6a and 6b) is characterized by the quasi absence of juvenile fragments. Fully crystallized gabbro fragments suggest that the emitted particles originate from intrusive levels of the caldera wall and from the destroyed, collapsed piston. The very scarce non-altered juvenile particles may belong to recent and still partially molten magmas stored at shallow levels within the lava pile that accumulated within the Dolomieu caldera, as molten lava flows within the newly formed caldera wall were visible just after the main collapse (Fig. 6b). These scarce juvenile particles cannot be related to the eruptive triggers, but the interstitial and relatively viscous melt within a crystal-rich gabbroic system might play a significant role in the fragmentation efficiency.

The coarser particles (> $125 \mu \mathrm{m}$ ) of the deposits generally show round or smooth shapes while the finer particles $(<63 \mu \mathrm{m})$ are mainly composed of blocky fragments of gabbroic crystals (Figs. 3b, 5e and 6). This is clearly evidenced by the SPH values that decrease toward finer grain sizes. SEM images (Fig. 3b and 6) confirm that the fine particles are significantly more angular than the coarse particles and that the coarse round particles are often fractured. The ash emissions observed during the April 2007 incremental caldera collapse at PdF have been firstly interpreted as phreatic driven, based on preliminary petrologic observations (Staudacher et al. 2009). The quasi absence of juvenile particles, and the presence of particle clusters, and montmorillonite (clay) and hematite phases, are in accordance with this first interpretation. As shown by analogue experiments (Buckland et al. 2018), we suggest that the coarse and fine particles are genetically linked, with the fine and blocky particles originating from the abrasion of the coarse and smoothed particles. We also suggest that wall rock abrasion and fragmentation was effective during the caldera piston collapse, forming a syn-collapse cataclasite as we observe very similar brittle features as those found within fault gauge (e.g. Engelder 1974; Marone and Sholtz 1989; Heilbronner and Keulen 2006), basal shear zones of thick lava flows (Latutrie et al. 2017), dome boundaries (Cashman et al. 2008) or conduit margins (Pallister et al. 2013). As these finely fractured rocks were transported in the atmosphere before deposition, we lost some of the features observed in typical fault gauge (such as the microstructures and faults as well as specific organizations of the particles). But our observations (Figs. 6c and 6d) support that the ash shapes produced during the April 2007 caldera collapse are very likely the product of fault- 
shear mechanism. The ubiquity of fine ash particles is also in accordance with this hypothesis, although elutriation mechanisms may occur within the ring fault system and during the collapse, preferentially injecting the fine ash particles into the atmosphere.

\subsubsection{The March 1860 violent Strombolian eruption: identification of phreatomagmatic interactions}

Contemporaneous observations suggest that the March 1860 eruption was triggered by a sudden arrival of hydrothermal and/or meteoritic water within the newly drained and still hot volcanic conduits and reservoirs (Michon et al. 2013). This hypothesis is supported by our results. The ubiquity of non-juvenile particles (89 to 98 $\%$ of gabbroic particles with rough or blocky shapes as well as altered recycled particles) suggest an origin of the emitted material from erosion of the conduit walls at different depths (Fig. 3c). The low juvenile content indicates that the magma involved was not sufficient to provoke such an eruption. Moreover, the scarce juvenile particles have a very low vesicle content. The contribution of external and/or hydrothermal fluids could have indeed provoked the fragmentation of the conduit wall rocks still partially hot and partially filled with molten juvenile magma ( 2 to $11 \%$ of observed juvenile ash). Small amount of hematite in these deposits may be related to acid leaching or post-depositional alteration due to the presence of hydrothermal fluids, even if further studies are needed to confirm this hypothesis. No significant morphology trends are observed in these two samples (Fig. 5f) due to the wide variety of ash components. However, CVX, SLD and SPH medians are systematically high, reflecting the presence of blocky particles associated with brittle fragmentation. Slightly higher AR values compared to the juvenile ash formed by ductile fragmentation, also suggest that no post-fragmentation deformation as well as no significant ductile mechanisms played a role in these phreatomagmatic eruptions.

\subsubsection{The Bellecombe Tephra: identification of phreatic explosions}

The investigated samples of the Bellecombe Tephra (BE_BASE_1 and BE_TOP_1) are only composed of non-juvenile particles. Alteration of the particles and presence of montmorillonite (clay) and quartz (generally formed within high temperatures hydrothermal systems) highlight that these particles were fragmented during phreatic phases that implicated one or several hydrothermal systems. We also suggest that these phreatic (and possibly phreatomagmatic for some layers which are not studied in this paper, Ort et al. 2016) explosions involve variably crystallized intrusive rocks, because of the presence of gabbro fragments, similarly to the March 1860 deposits. The presence of particle clusters can also be due to aggregation in the air favored by hydrothermal water, (Mueller et al. 2017) or post-depositional cementation (clay). Similarly to the phreatomagmatic deposits of the 
March 1860 eruption, no significant trends are observed in morphology data (Fig. 5g) and the ubiquity of the nonjuvenile blocky particles are revealed by the relatively high SPH measured values.

\subsection{Magmatic and/or non-magmatic fragmentation efficiencies}

The yellow field in Figure 7 show that the investigated Hawaiian deposits are moderately well sorted and with median grain size values skewed toward relatively coarse grains: the magma breakup (or ductile fragmentation) within lava fountains has a homogenous and moderate efficiency. Our results highlight that fragmentation efficiencies attained during Hawaiian activity at PdF is not necessarily correlated with the eruption intensities. When magma ascends in a conduit following a closed system degassing path and tends to crystallize, the fragmentation mechanism moves from ductile to brittle because of increasing viscosity. This higher fragmentation efficiency is recorded in the $\mathrm{CH} 1$ sample from the Black Tephra deposits of the Piton Chisny (orange circle in Fig. 7). The fact that this sample is very poorly sorted reflect the heterogeneity of the magmatic textures (ranging from crystal-poor and vesicle-rich sideromelane to crystal-rich and vesicle-poor tachylite particles) which plays a key role on the fragmentation mechanisms (ranging from ductile to brittle).

As soon as the lava flux decreases, the magmas have more time to degas, degassing moves from closed to open system, and the melt crystallizes within the eruptive conduit, increasing the magma viscosity. The deposits related to these mild Strombolian or transient explosions are well sorted and have relatively coarse grain size median values (grey field in Fig. 7): the partially brittle fragmentation during the bubble explosions at PdF has the weakest fragmentation efficiency investigated in this study and it is likely related to the transition from closed to open system degassing (large bubbles, volatile percolation and gas slugs). The tachylite deposits from the September 2016 eruption (big black circle in Fig. 7) reflects a better fragmentation efficiency enhanced by the overpressure caused by the local occurrence of a shallow and highly crystallized magma plug.

The deposit associated to the hydrovolcanic explosions caused by the lava entry in the sea observed during the April 2007 is very well sorted with an intermediate grain size median (blue triangle in Fig. 7), reflecting a quite efficient fragmentation, which results both from the lower temperature and fully degassed nature of the melt in the lava flows, producing an increase in melt viscosity with respect to conduit conditions.

The two samples representative of the March 1860 summit eruption (pink squares in Fig. 7) are well sorted and have intermediate median sizes. These results highlight that phreatomagmatic interactions enhance both magmas and surrounding rocks fragmentation. 
The Upper Bellecombe samples show lower median grain sizes and slightly better sorting compared to the Lower Bellecombe ones (green circles in Fig. 7). The wide range of median grain sizes and sorting that span the phreatomagmatic as well as phreatic deposits reflects the emission of heterogeneous tephra in terms of components and a potentially high fragmentation efficiency for some explosions.

Finally, the deposit related to the April 2007 caldera collapse event is interestingly the finest of this study (green square in Fig. 7) with an intermediate sorting value. We suggest that the addition of the phreatic explosions that occurred during the caldera collapse plus the secondary fault-shear fragmentation, may have produced the extreme fragmentation recorded by this very fine deposit. Scarce residual interstitial melt within the shallow magmatic system might also contribute to the gabbro fragmentation.

\section{Conclusions and risk implications}

In our study, we were able to identify a broad range of processes that control and/or enhance the magmatic and/or non-magmatic particle fragmentation at Piton de la Fournaise shield basaltic volcano. We list them here with their associated hazard implications.

(i) Hawaiian fountains usually produce a moderate amount of coarse ash during their ductile magmatic fragmentation. The hazard is related mostly to the formation of abundant Pele's hairs that can accumulate within proximal areas and sometimes in densely inhabited areas, like during the April 2007 eruption (Di Muro et al. 2015), impacting people and livestock due to their fibrous, acicular shape. More recently, the April 2020 eruption at PdF produced a large amount of Pele's hairs, which were found over a large part of the Reunion Island (Fig. S3, Table S4, http://opgc.fr/vobs/so_interface.php?so=dynvolc). In addition, a previous study showed that Pele's hairs, can host a large number of smaller particles, which represent a potential surface for heterogeneous nucleation of salts from the vapor phase (Moune et al. 2007). Ash particles in general can react with the acid gases during their transport in the volcanic plume and transport pollutants over a wide area (Delmelle et al. 2007).

(ii) Mild Strombolian explosions at PdF produce few ash during the bubbles (or slug) explosions at the magma free surface. However, syn-eruptive degassing-driven crystallization can enhance ash emissions because of the increase in magma viscosity, triggering brittle fragmentation of still gas-rich magmas. These relatively sudden changes in activity are unpredictable and can impact people approaching the eruptive sites. 

viscosity lava flows are likely to reach the ocean, sometimes creating gas and ash emissions. This also represents a risk to the local population because of the ash and shard fragments but also because of the acid gas emissions (Carlos et al. 2018). This emphasizes the need to monitor and anticipate the lava flow expansions and directions depending on the topography, lava flux and viscosity (Harris et al. 2019).

(iv) The presence of fluids at shallow levels within the PdF magmatic system has also been identified in this study as an amplifier of the magmatic and the country rock fragmentation. The interaction between magma and external fluids is interpreted as playing a potential role in some unusually high explosivity PdF eruptions (i.e. March 1860 eruption). In some cases, non-juvenile dense particle ubiquity within the investigated samples can be related to phreatic phases.

(v) Finally, secondary fault-shear fragmentation, have been identified as the most efficient mechanisms to form non-juvenile fine ash particles during the Dolomieu caldera collapse in April 2007. The extremely fine ash formed during such events, even if localized, can stay longer in suspension and can affect touristic and local populations. highlights the diversity of the basaltic fragmentation mechanisms at PdF (and this can be extrapolated to other basaltic volcanoes), which are important to understand in order to anticipate the associated hazards and potential risks. 

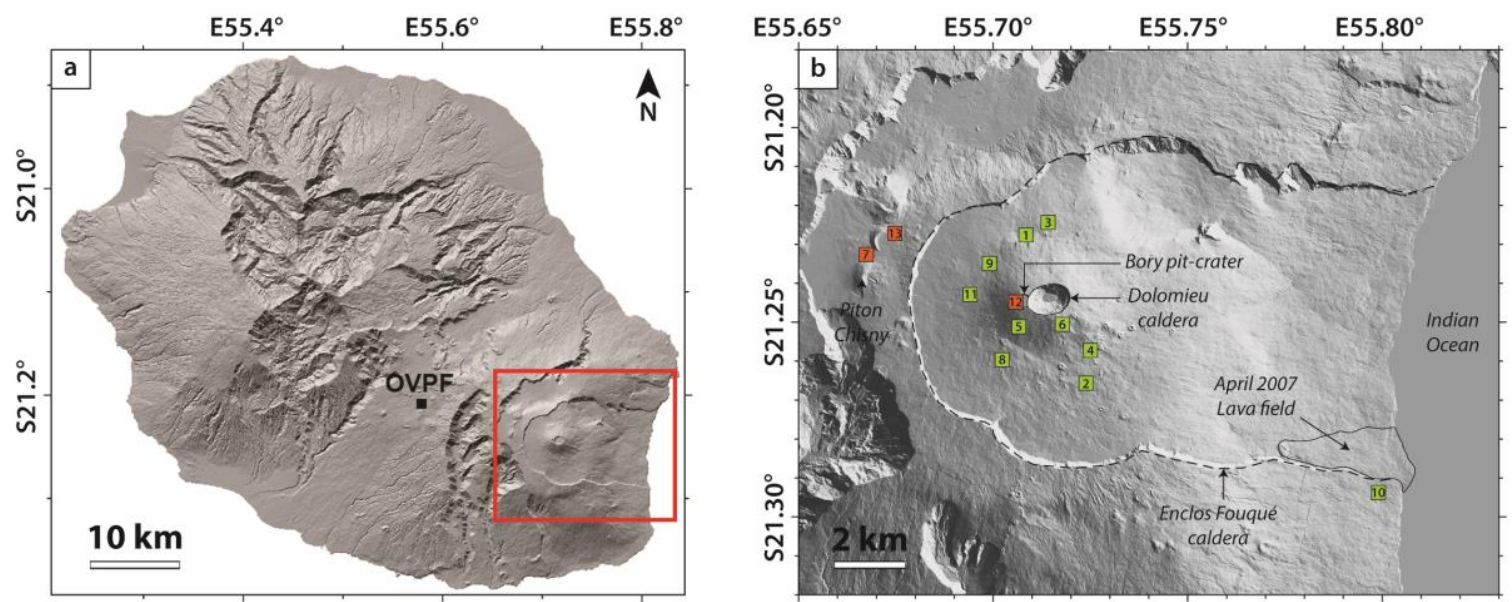

\begin{tabular}{|c|c|c|c|c|c|c|c|c|c|}
\hline \multirow{2}{*}{$\begin{array}{l}\text { Eruption } \\
\text { September } 2016\end{array}$} & \multirow{2}{*}{$\begin{array}{l}\text { Eruptive dynamics } \\
\text { Hawaiian fountaining }\end{array}$} & Sample name & \multicolumn{2}{|c|}{ Sample localisation } & \multirow[t]{2}{*}{$\begin{array}{c}\text { Distance } \\
\text { from the } \\
\text { source } \\
(\mathrm{m})\end{array}$} & \multirow[t]{2}{*}{$\begin{array}{c}\begin{array}{c}\text { Ash } \\
\text { fraction } \\
(<2 \mathrm{~mm}, \\
\mathbf{w} \%)^{\prime}\end{array} \\
10\end{array}$} & \multirow[t]{2}{*}{$\begin{array}{c}\begin{array}{c}\text { Fine ash } \\
\text { fraction } \\
(<64 \mu \mathrm{m}, \\
\text { wt\%) }\end{array} \\
0\end{array}$} & \multirow{2}{*}{$\begin{array}{c}\begin{array}{c}\text { Juvenile } \\
\text { ash (\%) }\end{array} \\
100\end{array}$} & \multirow{5}{*}{$\begin{array}{l}\text { Description of the eruptive activity and/or associated deposits } \\
\text { - Sustained Hawailian fountaining occurred at relatively high lava flux, } \\
\text { producing crystal-poor and vesicle-rich sideromelane (golden pumice and fluidal) pyroclasts } \\
\text { which are heterogeneous in term of grain size. }\end{array}$} \\
\hline & & & $\$ 21.22492^{\circ}$ & E55.70975 & & & & & \\
\hline & & REU1 & $521.26828^{\circ}$ & E55.72406 & & 27 & 0 & 100 & \\
\hline & & 2 REU160531_4 & & & & 13 & 0 & 100 & \\
\hline & & DREU160531_3 & & & & 14 & 0 & 100 & \\
\hline July 2015 & & 3] REU150731_4 & $521.22108^{\circ}$ & E55.71672 & & 58 & 0 & 100 & \\
\hline May 2015 & & 4 (4EU150520_3 & \$21.25895 & E55.72429 & & 13 & 0 & 100 & \\
\hline February 2015 & & 5 REU15 & $521.25013^{\circ}$ & E55.70 & & 31 & 0 & & \\
\hline June 2014 & & 6]REU141118_6 & $521.25085^{\circ}$ & E55.71919. & & 13 & 0 & 100 & \\
\hline $\begin{array}{l}\text { Piton Chisny } \\
\text { (1450 to } 1630 \text { AD) }\end{array}$ & Hawaiian fountaining & $7 \mathrm{CH}_{-}^{\mathrm{CH}}$ & $521.23368^{\circ}$ & E55.66518 & $\approx 400$ & 6 & 0 & 100 & $\begin{array}{l}\text { - Ash collected within the Piton Chisny black tephra deposits. } \\
\text { Cf login supplementarymaterial (Fig.S1) }\end{array}$ \\
\hline \multirow{2}{*}{$\begin{array}{l}\text { September } 2018 \\
\text { July } 2018\end{array}$} & Opening phase & BCH_1 & $\$ 21.25940^{\circ}$ & $E 55.70$ & 50 & 61 & $\begin{array}{c}5 \\
0\end{array}$ & 100 & \\
\hline & $\begin{array}{l}\text { Mild Strombolian } \\
\text { (opened vent) }\end{array}$ & $\begin{array}{l}\text { 8REU180916_3 } \\
\text { 9REU180807_7 }\end{array}$ & \$21.23518 & E55.69999" & & 5 & 0 & 100 & producing lapilli-dominated sideromelane pyroclasts for both erupti \\
\hline \multirow[t]{2}{*}{ September 2016} & Mild Strombolian & REU161211_6 & $521.22492^{\circ}$ & E55.70975 & 200 & 97 & 0 & 100 & - Relatively more energetic Strombolian explosions occured at relatively high lava flux, \\
\hline & (partially closed vent) & 'REU161211_10 & & & 100 & 8 & 0 & 100 & $\begin{array}{l}\text { producing (i) ash-dominated sporadic plumes (tachylite pyroclasts, REU161211_6), } \\
\text { and (ii) lapilli-dominated projections (dominance of sideromelane pyroclasts, REU161211_10) }\end{array}$ \\
\hline April 2007 & $\begin{array}{l}\text { Ash emission during } \\
\text { lava entry in the sea }\end{array}$ & 10 REU0704_052 & $\$ 21.29425^{\circ}$ & E55.79800 & 1000 & 99 & 1 & 100 & $\begin{array}{l}-5 \mathrm{~mm} \text { thick ash deposits collected on a clean surface after the main ash emission phase } \\
\text { from the shoreline delimited by the newly formed April } 2007 \text { lava flow. }\end{array}$ \\
\hline April 2007 & $\begin{array}{l}\text { Transient ash emission } \\
\text { during caldera collapse }\end{array}$ & 囵REU0704_171 & $521.24278^{\circ}$ & E55.69417 & 1500 & 100 & 87 & 1 & $\begin{array}{l}-4 \mathrm{~mm} \text { thick ash deposits collected on a clean surface after the main caldera collapse phase. } \\
\text { Ash were emitted during the formation of the caldera. }\end{array}$ \\
\hline March 1860 & Violent Strombolian & $\begin{array}{l}\text { REU131112 } \\
\text { RF__2 }\end{array}$ & $521.24376^{\circ}$ & E55.70639" & $\approx 500$ & $\begin{array}{c}56 \\
100\end{array}$ & $\begin{array}{l}1 \\
4\end{array}$ & $\begin{array}{c}2 \\
11\end{array}$ & $\begin{array}{l}\text { - Ash collected within the lower part of the stratigraphic log described in Michon et al. (2013). } \\
\text { Cf. log in supplementary material (Fig. S1). }\end{array}$ \\
\hline \multirow{3}{*}{$\begin{array}{l}\text { Bellecombe ash } \\
\text { (4900 to } 2250 \mathrm{BP})\end{array}$} & Unknow & BE_TOP_2 2 & $521.22724^{\circ}$ & E55.67450 & $\approx 500$ & 59 & 2 & 0 & layers of the stratigraphic log described in Ort et al. (2016). \\
\hline & $\begin{array}{l}\text { deposits related the } \\
\text { decompression of }\end{array}$ & BE_TOP_1 & & & & 47 & 3 & 0 & C. $\log$ in the supplementary material (Fig. S2). \\
\hline & $\begin{array}{l}\text { decompression of } \\
\text { shallow systems }\end{array}$ & BE_BASE_2 & & & unknc & $\begin{array}{l}91 \\
85\end{array}$ & 11 & $\begin{array}{l}0 \\
0\end{array}$ & $\begin{array}{l}\text { «BASE» samples correspond to the Lower Bellecombe Tephra (LBT). } \\
\text { «TOP» samples correspond to the Upper Bellecombe Tephra (UBT). }\end{array}$ \\
\hline
\end{tabular}

Fig. 1 - (a) Digital Elevation Model of La Reunion Island hosting the Piton de la Fournaise (PdF) volcano (red square) and the Observatoire Volcanologique du Piton de la Fournaise (OVPF). (b) Map of PdF volcano with the studied deposits. The green and orange squares correspond to the deposits sampled during recent activity (20142018) and historical eruptions, respectively. (c) List and description of all the studied samples. The percentage of juvenile ash is measured on specific grain size bins which are described in the results part. 


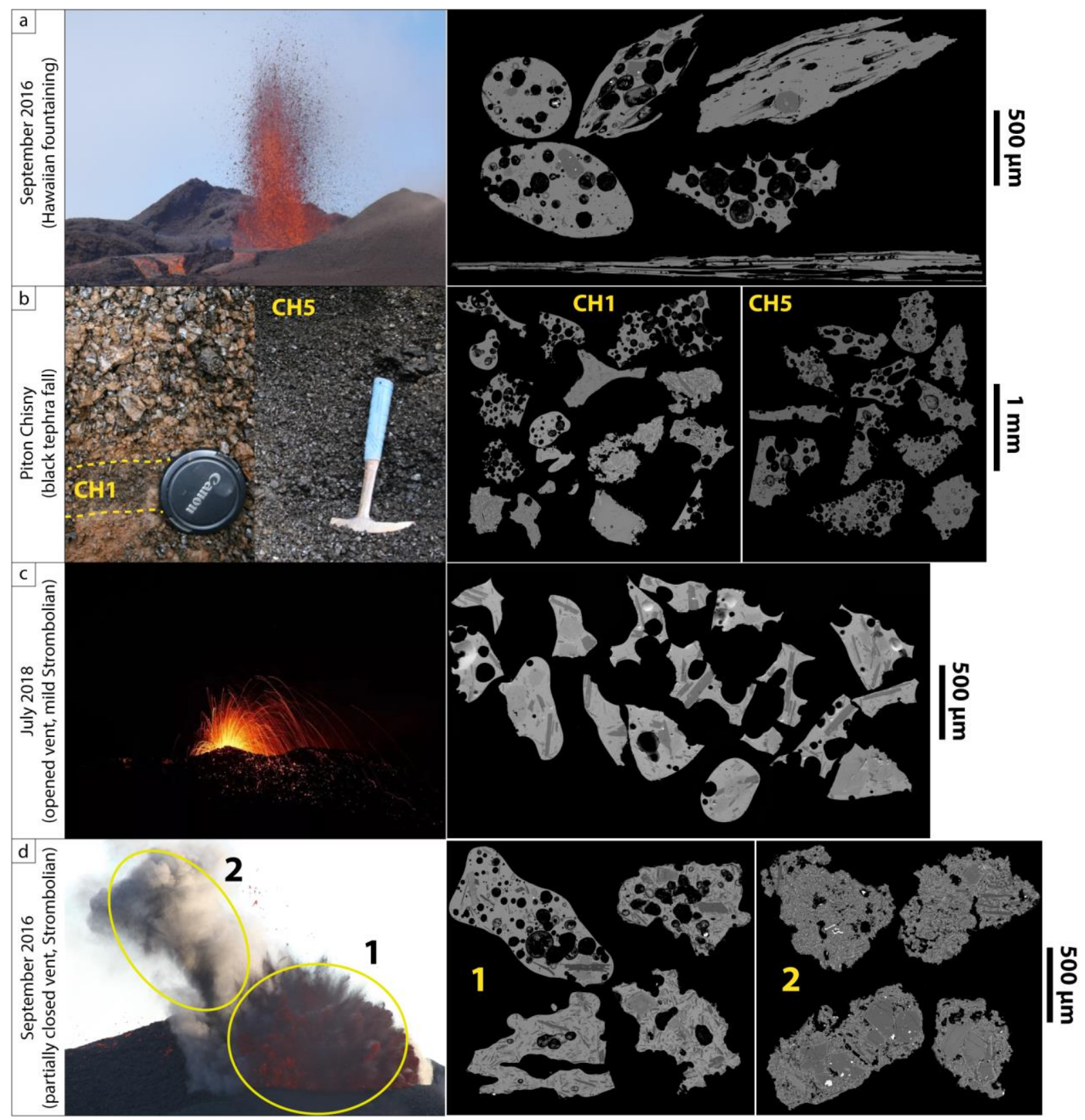

Fig. 2 - Eruptions and deposits pictures and Backscattered Electron Scanning Microscope (SEM-BSE) images of

693 the respective ash particles, part 1. (a) Hawaiian fountaining activity producing golden pumice and fluidal scoria pyroclasts. (b) Deposits from intense Hawaiian fountaining. $\mathrm{CH} 1$ corresponds to the initial phase and CH5 corresponds to the later, steady phase. (c) Mild Strombolian activity producing sideromelane pyroclasts. (d) Transient explosions producing incandescent particules (sideromelane pyroclasts, labelled 1) associated with 


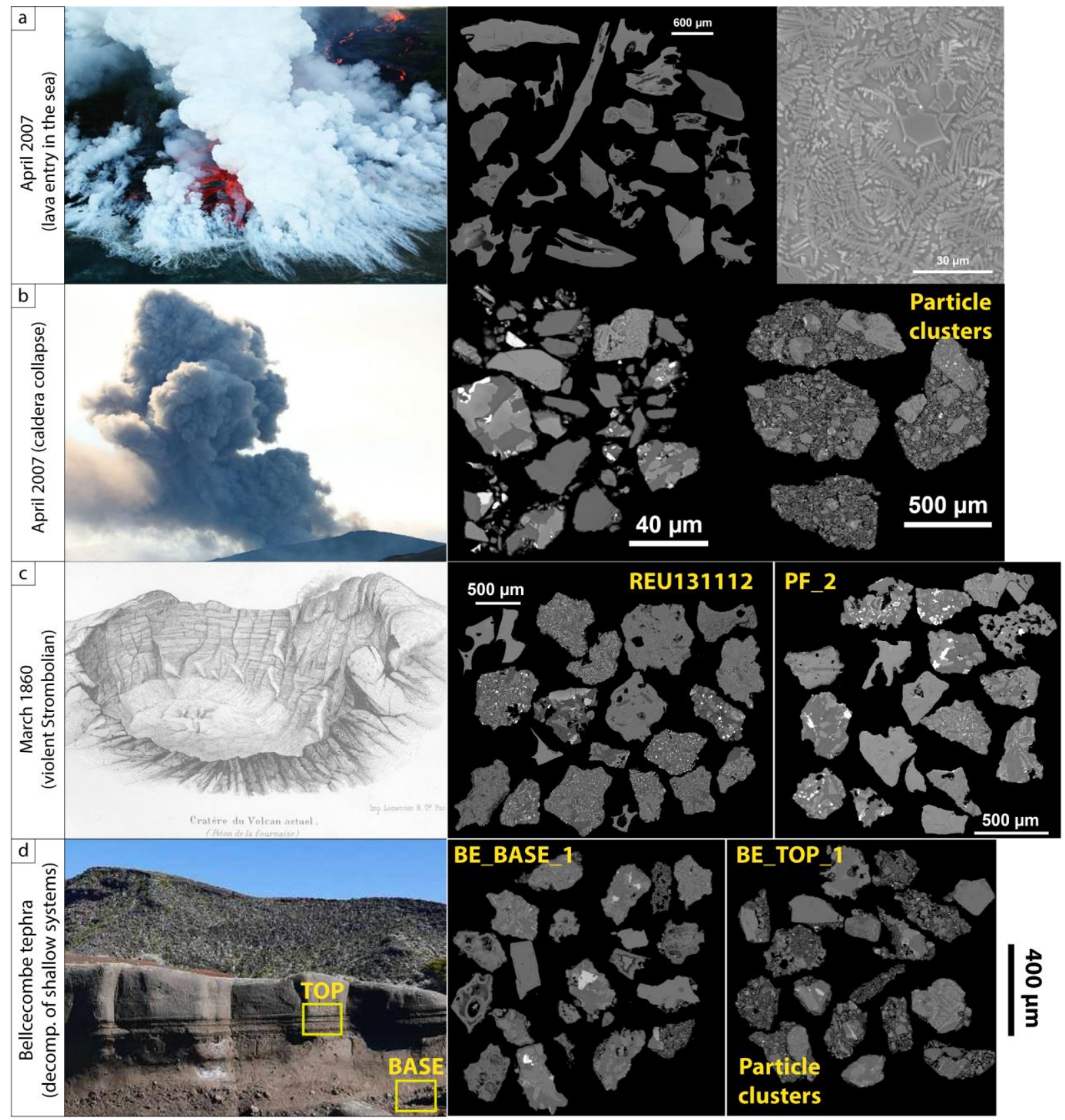

701 Fig. 3 - Eruptions and deposits pictures and SEM-BSE images of the respective ash particles, part 2. (a) Lava entry in the sea producing a laze and ash emission. (b) Ash emission during major caldera collapse at PdF. Particles within the particle clusters are randomly distributed. (c) Ash deposits from the March 1860 summit eruption at PdF. Sketch from Velain (1878) representing the Brûlant crater a few years after the eruption. (d) Bellecombe tephra. Particles within the particle clusters are randomly distributed. 

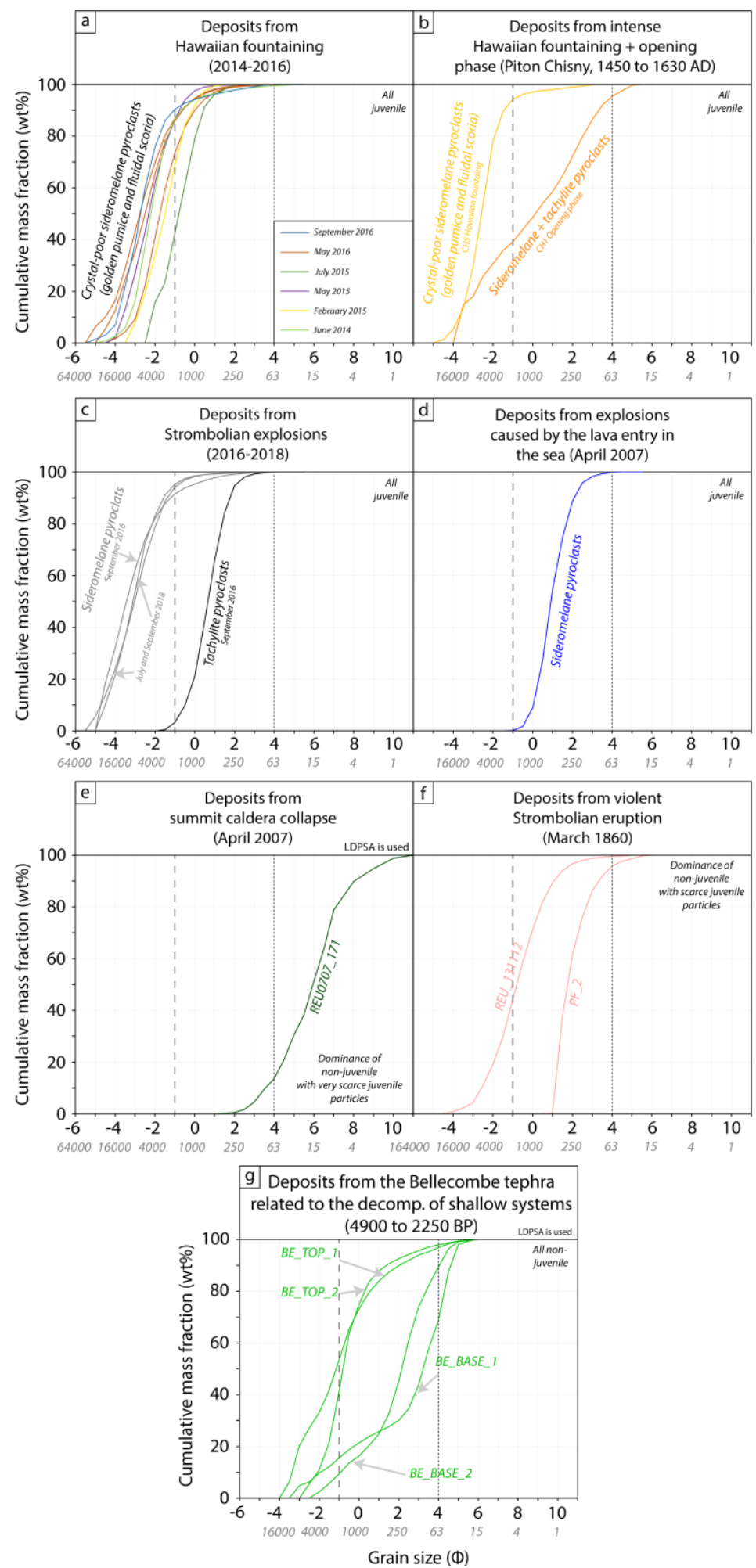

Grain size $(\Phi)$

709 Fig. 4 - Particle Size Distribution of the different studied deposits. Coarse ash boundary is represented by the black dashed line at $-1 \Phi(2 \mathrm{~mm})$. Fine ash boundary is represented by the black dashed line at $4 \Phi(64 \mathrm{~mm})$. The samples are represented with a color code reflecting their associated eruptive styles. LDPSA is for Laser 


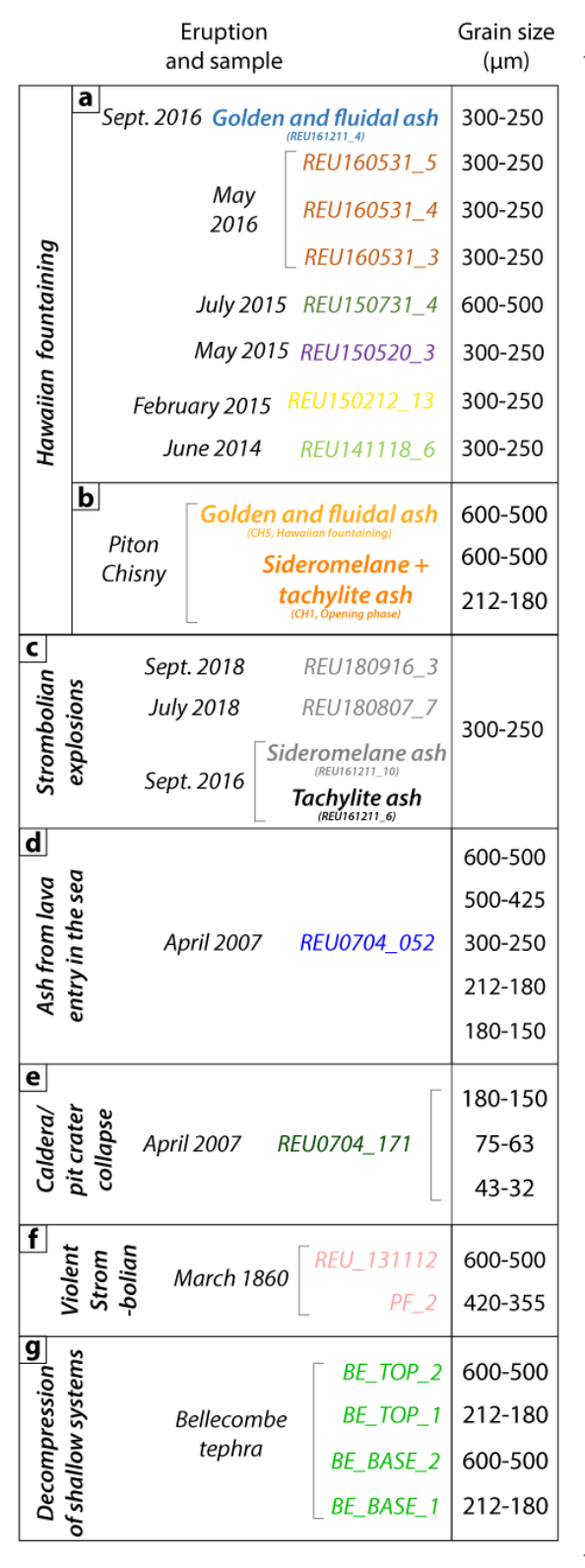
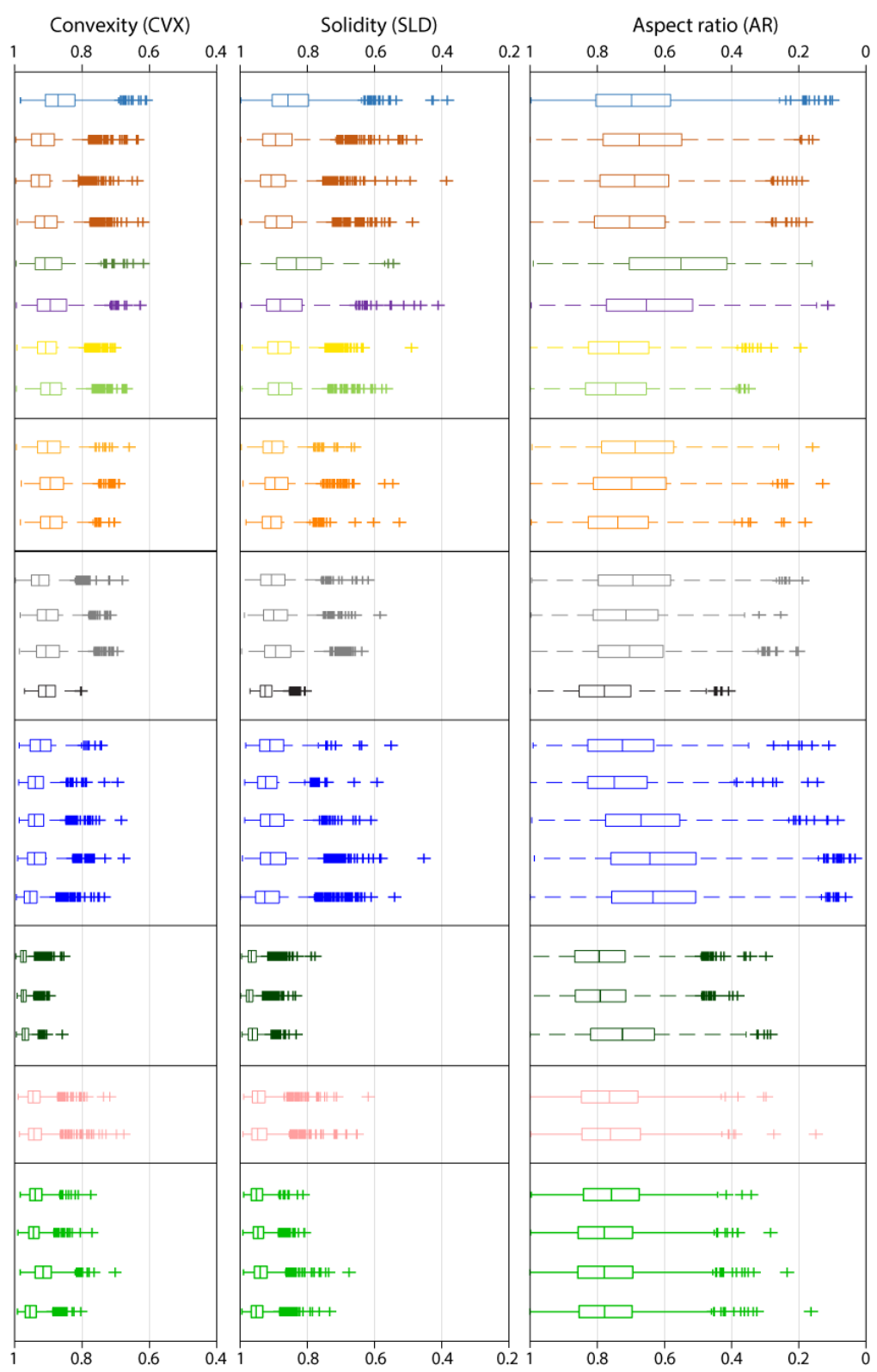

Fig. 5 - Apparent Projected Shape of Ash for each sample, in terms of convexity, solidity and aspect ratio, with the grain size used for each measurement. Vertical line within the boxes represents the median and box boundaries represent the $25^{\text {th }}$ and $75^{\text {th }}$ percentiles of each dataset. Error bars represent $2.7 \sigma$ of each dataset and outlier data are represented with crosses. Sample color code as per Figure 4. 


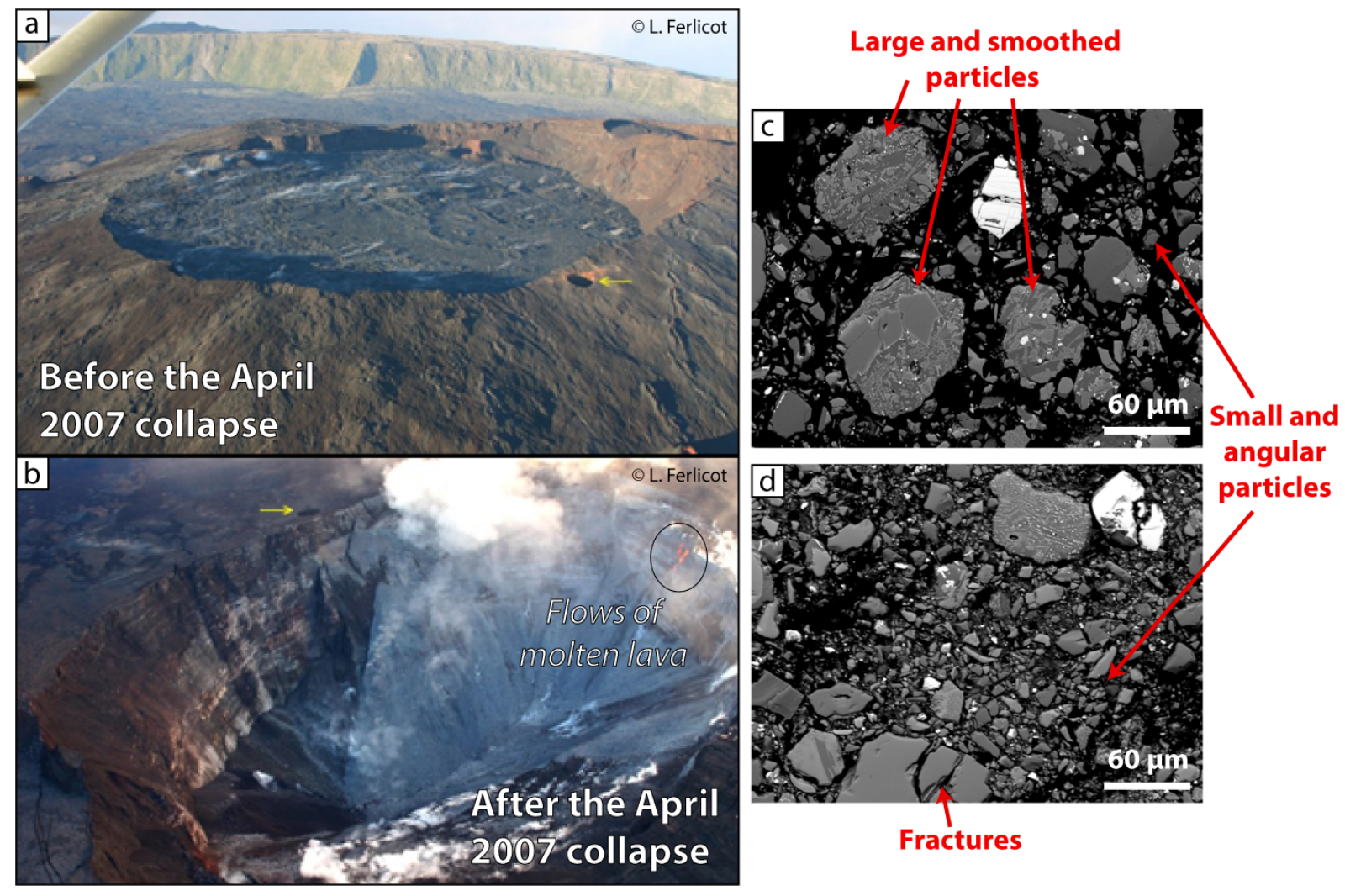

Fig. 6 - The Dolomieu caldera of PdF before (a) and after (b) the collapse, with visible lava flows. The yellow arrows mark the La Soufrière crater. (c) and (d) SEM-BSE images of the products emitted during the collapse. 


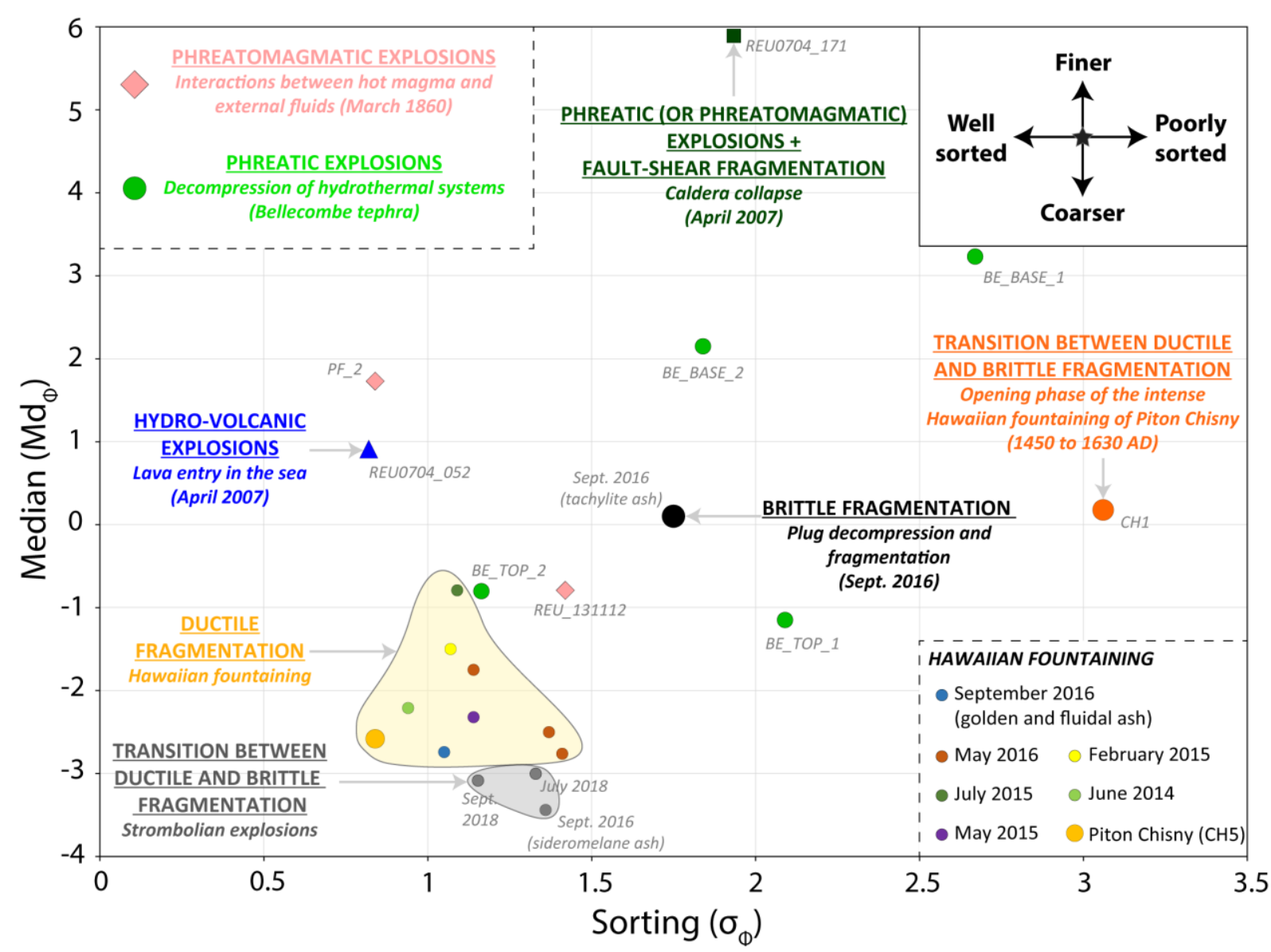

Fig. 7 - Median $\left(\operatorname{Md}_{\Phi}\right)$ vs. sorting $\left(\sigma_{\Phi}\right)$ plot. Sample color code as in Figures 4 and 5. Considering the proximal nature and similar sampling distance of all samples, $\mathrm{Md}_{\Phi}$ is mostly considered as a fragmentation efficiency proxy, and $\sigma_{\Phi}$ reflects the degree of homogeneity of the deposits in term of texture, of componentry, and thus of 


\section{References}

Andronico, D., Scollo, S., \& Cristaldi, A. (2015). Unexpected hazards from tephra fallouts at Mt Etna: The 23 November 2013 lava fountain. Journal of Volcanology and Geothermal Research, 304, 118-125. https://doi.org/10.1016/j.jvolgeores.2015.08.007

Andronico, D., \& Corsaro, R. A. (2011). Lava fountains during the episodic eruption of South-East Crater (Mt. Etna), 2000: insights into magma-gas dynamics within the shallow volcano plumbing system. Bulletin of Volcanology, 73(9), 1165-1178. doi:10.1007/s00445-011-0467-y

Andronico, D., Corsaro, R. A., Cristaldi, A., \& Polacci, M. (2008). Characterizing high energy explosive eruptions at Stromboli volcano using multidisciplinary data: An example from the 9 January 2005 explosion. Journal of Volcanology and Geothermal Research, 176(4), 541-550. https://doi.org/10.1016/j.jvolgeores.2008.05.011

Applegarth, L. Jane, Tuffen, H., James, M. R., Pinkerton, H., \& Cashman, K. V. (2013). Direct observations of degassing-induced crystallization in basalts. Geology, 41(2), 243-246. https://doi.org/10.1130/G33641.1

Arzilli, F., La Spina, G., Burton, M. R., Polacci, M., Le Gall, N., Hartley, M. E., ... \& Nonni, S. (2019). Magma fragmentation in highly explosive basaltic eruptions induced by rapid crystallization. Nature Geoscience, 12(12), 1023-1028.

Arzilli, F., Agostini, C., Landi, P., Fortunati, A., Mancini, L., \& Carroll, M. R. (2015). Plagioclase nucleation and growth kinetics in a hydrous basaltic melt by decompression experiments. Contributions to Mineralogy and Petrology, 170(5-6), 1-16. https://doi.org/10.1007/s00410-015-1205-9

Brown, R. J., Bonadonna, C., \& Durant, A. J. (2012). A review of volcanic ash aggregation. Physics and Chemistry of the Earth, 45-46, 65-78. https://doi.org/10.1016/j.pce.2011.11.001

Buckland, H. M., Eychenne, J., Rust, A. C., \& Cashman, K. V. (2018). Relating the physical properties of volcanic rocks to the characteristics of ash generated by experimental abrasion. Journal of Volcanology and Geothermal Research, 349, 335-350. https://doi.org/10.1016/j.jvolgeores.2017.11.017

Büttner, R., Dellino, P., \& Zimanowski, B. (1999). Identifying magma-water interaction from the surface features of ash particles. Nature, 401(6754), 688-690. doi:10.1038/44364 
Cannata, C. B., De Rosa, R., Donato, P., Donato, S., Lanzafame, G., Mancini, L., \& Houghton, B. F. (2019). First 3D imaging characterization of Pele's hair from Kilauea volcano (Hawaii). Scientific Reports, 9(1), 1711. https://doi.org/10.1038/s41598-018-37983-9

Carlos, W. G., Gross, J. E., Jamil, S., Dela Cruz, C. S., Damby, D., \& Tam, E. (2018). Volcanic Eruptions and Threats to Respiratory Health. American Journal of Respiratory and Critical Care Medicine, 197(12), P21P22. https://doi.org/10.1164/rccm.19712P21

Cashman, K. V., \& Scheu, B. (2015). Magmatic fragmentation. In The encyclopedia of volcanoes (pp. 459-471). Academic Press. https://doi.org/10.1016/B978-0-12-385938-9.00025-0

Cashman, K. V., Thornber, C. R., \& Pallister, J. S. (2008). From dome to dust: Shallow crystallization and fragmentation of conduit magma during the 2004-2006 dome extrusion of Mount St. Helens, Washington (No. 1750-19, pp. 387-413). US Geological Survey. https://doi.org/10.3133/pp175019

Chouet, B., Dawson, P., Ohminato, T., Martini, M., Saccorotti, G., Giudicepietro, F., ... Scarpa, R. (2003). Source mechanisms of explosions at Stromboli Volcano, Italy, determined from moment-tensor inversions of verylong-period data. Journal of Geophysical Research: Solid Earth, 108(B1), ESE 7-1-ESE 7-25. https://doi.org/10.1029/2002jb001919

Cimarelli, C., Di Traglia, F., \& Taddeucci, J. (2010). Basaltic scoria textures from a zoned conduit as precursors to violent Strombolian activity. Geology, 38(5), 439-442. https://doi.org/10.1130/G30720.1

Coppola, D., Di Muro, A., Peltier, A., Villeneuve, N., Ferrazzini, V., Favalli, M., ... Aiuppa, A. (2017). Shallow system rejuvenation and magma discharge trends at Piton de la Fournaise volcano (La Réunion Island). Earth and Planetary Science Letters, 463, 13-24. doi:10.1016/j.epsl.2017.01.024

Corsaro, R. A., Andronico, D., Behncke, B., Branca, S., Caltabiano, T., Ciancitto, F., ... Spata, G. (2017). Monitoring the December 2015 summit eruptions of Mt. Etna (Italy): Implications on eruptive dynamics. Journal of Volcanology and Geothermal Research, 341(December 2015), 53-69. https://doi.org/10.1016/j.jvolgeores.2017.04.018

D’Oriano, C., Bertagnini, A., Cioni, R., \& Pompilio, M. (2014). Identifying recycled ash in basaltic eruptions. Scientific Reports, 4(1), 5851. https://doi.org/10.1038/srep05851

Delmelle, P., Lambert, M., Dufrêne, Y., Gerin, P., \& Óskarsson, N. (2007). Gas/aerosol-ash interaction in volcanic 
plumes: New insights from surface analyses of fine ash particles. Earth and Planetary Science Letters, 259(12), 159-170. doi:10.1016/j.epsl.2007.04.052

Di Muro, A., Staudacher, T., Ferrazzini, V., Métrich, N., Besson, P., Garofalo, C., \& Villemant, B. (2015). Shallow Magma Storage at Piton de la Fournaise Volcano After 2007 Summit Caldera Collapse Tracked in Pele's Hairs. In American Geophysical Union Monograph (Vol. 208, pp. 189-212). https://doi.org/10.1002/9781118872079.ch9

Di Muro, A., Metrich, N., Vergani, D., Rosi, M., Armienti, P., Fougeroux, T., ... Civetta, L. (2014). The Shallow Plumbing System of Piton de la Fournaise Volcano (La Reunion Island, Indian Ocean) Revealed by the Major 2007 Caldera-Forming Eruption. Journal of Petrology, 55(7), 1287-1315. https://doi.org/10.1093/petrology/egu025

Dvorak, J. J. (1992). Mechanism of explosive eruptions of Kilauea Volcano, Hawaii. Bulletin of Volcanology, 54(8), 638-645. https://doi.org/10.1007/BF00430777

Engelder, J. (1974). Cataclasis and the Generation of Fault Gouge. Geological Society of America Bulletin, 85(10), 1515. https://doi.org/10.1130/0016-7606(1974)85<1515:CATGOF>2.0.CO;2

Eychenne, J., Le Pennec, J.-L., Troncoso, L., Gouhier, M., \& Nedelec, J.-M. (2012). Causes and consequences of bimodal grain-size distribution of tephra fall deposited during the August 2006 Tungurahua eruption (Ecuador). Bulletin of Volcanology, 74(1), 187-205. https://doi.org/10.1007/s00445-011-0517-5

Fontaine, F R., Roult, G., Michon, L., Barruol, G., \& Muro, A. Di. (2014). The 2007 eruptions and caldera collapse of the Piton de la Fournaise volcano (La Réunion Island) from tilt analysis at a single very broadband seismic station. Geophysical Research Letters, 41(8), 2803-2811. https://doi.org/10.1002/2014GL059691

Guffanti, M., \& Tupper, A. (2015). Volcanic Ash Hazards and Aviation Risk. Volcanic Hazards, Risks and Disasters, 87-108. https://doi.org/10.1016/b978-0-12-396453-3.00004-6

Gurioli, L., Di Muro, A., Vlastélic, I., Moune, S., Thivet, S., Valer, M., ... Hénot, J.-M. (2018). Integrating field, textural, and geochemical monitoring to track eruption triggers and dynamics: a case study from Piton de la Fournaise. Solid Earth, 9(2), 431-455. https://doi.org/10.5194/se-9-431-2018

Gurioli, L., Colo', L., Bollasina, A. J., Harris, A. J. L., Whittington, A., \& Ripepe, M. (2014). Dynamics of Strombolian explosions: Inferences from field and laboratory studies of erupted bombs from Stromboli 

https://doi.org/10.1002/2013JB010355

Harris, A. J., Chevrel, M. O., Coppola, D., Ramsey, M., Hrysiewicz, A., Thivet, S., ... \& Di Muro, A. (2019). Validation of an integrated satellite-data-driven response to an effusive crisis: the April-May 2018 eruption of Piton de la Fournaise. https://doi.org/10.4401/ag-7972

Harris, A., \& Ripepe, M. (2007). Synergy of multiple geophysical approaches to unravel explosive eruption conduit and source dynamics-A case study from Stromboli. Geochemistry, 67(1), 1-35. https://doi.org/10.1016/j.chemer.2007.01.003

Heilbronner, R., \& Keulen, N. (2006). Grain size and grain shape analysis of fault rocks. Tectonophysics, 427(14), 199-216. https://doi.org/10.1016/j.tecto.2006.05.020

Horwell, C. J., \& Baxter, P. J. (2006). The respiratory health hazards of volcanic ash: A review for volcanic risk mitigation. Bulletin of Volcanology, 69(1), 1-24. https://doi.org/10.1007/s00445-006-0052-y

Houghton, B. F., Taddeucci, J., Andronico, D., Gonnermann, H. M., Pistolesi, M., Patrick, M. R., ... Scarlato, P. (2016). Stronger or longer: Discriminating between Hawaiian and Strombolian eruption styles. Geology, 44(2), 163-166. https://doi.org/10.1130/G37423.1

Houghton, B. F., \& Gonnermann, H. M. (2008). Basaltic explosive volcanism: Constraints from deposits and models. Geochemistry, 68(2), 117-140. https://doi.org/10.1016/j.chemer.2008.04.002

Jaupart, C., \& Vergniolle, S. (1989). The generation and collapse of a foam layer at the roof of a basaltic magma chamber. Journal of Fluid Mechanics, 203(347), 347. https://doi.org/10.1017/S0022112089001497

Jaupart, C., \& Vergniolle, S. (1988). Laboratory models of Hawaiian and Strombolian eruptions. Nature, 331(6151), 58-60. https://doi.org/10.1038/331058a0

Latutrie, B., Harris, A., Médard, E., \& Gurioli, L. (2017). Eruption and emplacement dynamics of a thick trachytic lava flow of the Sancy volcano (France). Bulletin of Volcanology, 79(1), 4. https://doi.org/10.1007/s00445016-1084-6

Lautze, N. C., Taddeucci, J., Andronico, D., Cannata, C., Tornetta, L., Scarlato, P., .. Lo Castro, M. D. (2012). SEM-based methods for the analysis of basaltic ash from weak explosive activity at Etna in 2006 and the 
Leibrandt, S., \& Le Pennec, J.-L. (2015). Towards fast and routine analyses of volcanic ash morphometry for eruption surveillance applications. Journal of Volcanology and Geothermal Research, 297, 11-27. https://doi.org/10.1016/j.jvolgeores.2015.03.014

Lénat, J.-F. (2016). A Brief History of the Observation of the Central Area of Piton de la Fournaise. In Active volcanoes of the Southwest Indian Ocean: Piton de la Fournaise and Karthala (pp. 3-21). https://doi.org/10.1007/978-3-642-31395-0_1

Liu, E. J., Cashman, K. V., \& Rust, A. C. (2015). Optimising shape analysis to quantify volcanic ash morphology. GeoResJ, 8, 14-30. https://doi.org/10.1016/j.grj.2015.09.001

Maicher, D., White, J. (2001). The formation of deep-sea Limu o Pele. Bulletin of Volcanology, 63(7), 482-496. https://doi.org/10.1007/s004450100165

Mangan, MT., Cashman KV., Swanson DA. (2014). The dynamics of Hawaiian-style eruptions: a century of study. Chap. 8 in Poland, MP., Takahashi, TJ., Landowski, CM., eds., Characteristics of Hawaiian volcanoes: U.S. Geological Survey Professional Paper 1801, P. 323-354. https://doi.org/10.3133/pp18018

Marone, C., \& Scholz, C. H. (1989). Particle-size distribution and microstructures within simulated fault gouge. Journal of Structural Geology, 11(7), 799-814. https://doi.org/10.1016/0191-8141(89)90099-0

Mastin, L. G. (1997). Evidence for water influx from a caldera lake during the explosive hydromagmatic eruption of 1790, Kilauea volcano, Hawaii. Journal of Geophysical Research: Solid Earth, 102(B9), 20093-20109. https://doi.org/10.1029/97jb01426

Mattox, T. N., \& Mangan, M. T. (1997). Littoral hydrovolcanic explosions: A case study of lava-seawater interaction at Kilauea Volcano. Journal of Volcanology and Geothermal Research, 75(1-2), 1-17. https://doi.org/10.1016/S0377-0273(96)00048-0Michon, L., Ferrazzini, V., \& Di Muro, A. (2016). Magma Paths at Piton de la Fournaise Volcano. In Active Volcanoes of the Southwest Indian Ocean. Active Volcanoes of the World. (pp. 91-106). https://doi.org/10.1007/978-3-642-31395-0_7

Michon, L., Di Muro, A., Villeneuve, N., Saint-Marc, C., Fadda, P., \& Manta, F. (2013). Explosive activity of the summit cone of Piton de la Fournaise volcano (La Réunion island): A historical and geological review. 

https://doi.org/10.1016/j.jvolgeores.2013.06.012

Michon, L., Massin, F., Famin, V., Ferrazzini, V., \& Roult, G. (2011). Basaltic calderas: Collapse dynamics, edifice deformation, and variations of magma withdrawal. Journal of Geophysical Research, 116(B3), B03209. https://doi.org/10.1029/2010JB007636

Michon, L., \& Saint-Ange, F. (2008). Morphology of Piton de la Fournaise basaltic shield volcano (La Réunion Island): Characterization and implication in the volcano evolution. Journal of Geophysical Research: Solid Earth, 113(3), 1-19. https://doi.org/10.1029/2005JB004118

Michon, L., Staudacher, T., Ferrazzini, V., Bachèlery, P., \& Marti, J. (2007). April 2007 collapse of Piton de la Fournaise: A new example of caldera formation. Geophysical Research Letters, 34(21), 1-6. https://doi.org/10.1029/2007GL031248

Morandi, A., Di Muro, A., Principe, C., Michon, L., Leroi, G., Norelli, F., \& Bachèlery, P. (2016). Pre-historic ( $<5$ kiloyear) Explosive Activity at Piton de la Fournaise Volcano. In Active Volcanoes of the Southwest Indian Ocean. Active Volcanoes of the World. (pp. 107-138). https://doi.org/10.1007/978-3-642-31395-0_8

Moune, S., Faure, F., Gauthier, P.-J., \& Sims, K. W. W. (2007). Pele's hairs and tears: Natural probe of volcanic plume. Journal of Volcanology and Geothermal Research, 164(4), 244-253. https://doi.org/10.1016/j.jvolgeores.2007.05.007

Mueller, S. B., Ayris, P. M., Wadsworth, F. B., Kueppers, U., Casas, A. S., Delmelle, P., ... Dingwell, D. B. (2017). Ash aggregation enhanced by deposition and redistribution of salt on the surface of volcanic ash in eruption plumes. Scientific Reports, 7(1). https://doi.org/10.1038/srep45762

Neal, C. A., Brantley, S. R., Antolik, L., Babb, J. L., Burgess, M., Calles, K., .. Damby, D. (2019). The 2018 rift eruption and summit collapse of Kīlauea Volcano. Science, 363(6425), 367-374. https://doi.org/10.1126/science.aav7046

Oppenheimer, J., Capponi, A., Cashman, K. V., Lane, S. J., Rust, A. C., \& James, M. R. (2020). Analogue experiments on the rise of large bubbles through a solids-rich suspension: A "weak plug" model for Strombolian eruptions. Earth and Planetary Science Letters, 531, 115931. https://doi.org/10.1016/j.epsl.2019.115931 
Ort, M. H., Di Muro, A., Michon, L., \& Bachèlery, P. (2016). Explosive eruptions from the interaction of magmatic and hydrothermal systems during flank extension: the Bellecombe Tephra of Piton de La Fournaise (La Réunion Island). Bulletin of Volcanology, 78(1), 5. https://doi.org/10.1007/s00445-015-0998-8

Pallister, J. S., Cashman, K. V., Hagstrum, J. T., Beeler, N. M., Moran, S. C., \& Denlinger, R. P. (2013). Faulting within the Mount St. Helens conduit and implications for volcanic earthquakes. Geological Society of America Bulletin, 125(3-4), 359-376. https://doi.org/10.1130/B30716.1

Parcheta, C. E., Houghton, B. F., \& Swanson, D. A. (2013). Contrasting patterns of vesiculation in low, intermediate, and high Hawaiian fountains: A case study of the 1969 Mauna Ulu eruption. Journal of Volcanology and Geothermal Research, 255, 79-89. https://doi.org/10.1016/j.jvolgeores.2013.01.016

Peltier, A., Villeneuve, N., Ferrazzini, V., Testud, S., Hassen Ali, T., Boissier, P., \& Catherine, P. (2018). Changes in the Long-Term Geophysical Eruptive Precursors at Piton de la Fournaise: Implications for the Response Management. Frontiers in Earth Science, 6(July), 1-10. https://doi.org/10.3389/feart.2018.00104

Pioli, L., Pistolesi, M., \& Rosi, M. (2014). Transient explosions at open-vent volcanoes: The case of Stromboli (Italy). Geology, 42(10), 863-866. https://doi.org/10.1130/G35844.1

Polacci, M., Andronico, D., de’ Michieli Vitturi, M., Taddeucci, J., \& Cristaldi, A. (2019). Mechanisms of Ash Generation at Basaltic Volcanoes: The Case of Mount Etna, Italy. Frontiers in Earth Science, 7(August). https://doi.org/10.3389/feart.2019.00193

Polacci, M., Burton, M. R., La Spina, A., Murè, F., Favretto, S., \& Zanini, F. (2009). The role of syn-eruptive vesiculation on explosive basaltic activity at Mt. Etna, Italy. Journal of Volcanology and Geothermal Research, 179(3-4), 265-269. https://doi.org/10.1016/j.jvolgeores.2008.11.026

Polacci, M., Corsaro, R. A., Andronico, D. (2006). Coupled textural and compositional characterization of basaltic scoria: Insights into the transition from Strombolian to fire fountain activity at Mount Etna, Italy. Geology, 34(3), 201-204. https://doi.org/10.1130/G22318.1

Porritt, L. A., Russell, J. K., \& Quane, S. L. (2012). Pele’s tears and spheres: Examples from Kilauea Iki. Earth and Planetary Science Letters, 333-334, 171-180. https://doi.org/10.1016/j.eps1.2012.03.031

Potter, N. J., Carey, R. J., Andronico, D., \& Costantini, L. (2019). Eruption dynamics of the 23 February 2013 event at Mt. Etna. Journal of Volcanology and Geothermal Research, 384, 241-250. 
Potuzak, M., Nichols, A. R. L., Dingwell, D. B., \& Clague, D. A. (2008). Hyperquenched volcanic glass from Loihi Seamount, Hawaii. Earth and Planetary Science Letters, 270(1-2), 54-62. https://doi.org/10.1016/j.eps1.2008.03.018

Principe, C., Morandi, A., Di Muro, A., \& Michon, L. (2016). Volcanological Map of the Plaine des Sables, Piton de la Fournaise. In Active Volcanoes of the Southwest Indian Ocean. Active Volcanoes of the World. (pp. 327-330). https://doi.org/10.1007/978-3-642-31395-0_20

Riley, C. M., Rose, W. I., \& Bluth, G. J. S. (2003). Quantitative shape measurements of distal volcanic ash. Journal of Geophysical Research: Solid Earth, 108(B10), 1-15. https://doi.org/10.1029/2001jb000818

Ripepe, M., Marchetti, E., Ulivieri, G., Harris, A., Dehn, J., Burton, M., ... Salerno, G. (2005). Effusive to explosive transition during the 2003 eruption of Stromboli volcano. Geology, 33(5), 341-344. https://doi.org/10.1130/G21173.1

Ripepe, M., Ciliberto, S., \& Della Schiava, M. (2001). Time constraints for modeling source dynamics of volcanic explosions at Stromboli. Journal of Geophysical Research: Solid Earth, 106(B5), 8713-8727. https://doi.org/10.1029/2000JB900374

Sable, J. E., Houghton, B. F., Del Carlo, P., \& Coltelli, M. (2006). Changing conditions of magma ascent and fragmentation during the Etna 122 BC basaltic Plinian eruption: Evidence from clast microtextures. Journal of Volcanology and Geothermal Research, 158(3-4), 333-354. https://doi.org/10.1016/j.jvolgeores.2006.07.006

Schmid, R. (1981). Descriptive nomenclature and classification of pyroclastic deposits and fragments. Geologische Rundschau, 70(2), 794-799. https://doi.org/10.1007/BF01822152

Shimozuru, D. (1994). Physical parameters governing the formation of Pele's hair and tears. Bulletin of Volcanology, 56(3), 217-219. https://doi:10.1007/bf00279606

Simakin, A. G., Armienti, P., \& Epel'baum, M. B. (1999). Coupled degassing and crystallization: Experimental study at continuous pressure drop, with application to volcanic bombs. Bulletin of Volcanology, 61(5), 275287. https://doi.org/10.1007/s004450050297 
Song, W., Hess, K.-U., Damby, D. E., Wadsworth, F. B., Lavallée, Y., Cimarelli, C., and Dingwell, D. B. ( 2014), Fusion characteristics of volcanic ash relevant to aviation hazards, Geophys. Res. Lett., 41, 2326- 2333, https://doi.org/10.1002/2013GL059182.

Spina, L., Taddeucci, J., Cannata, A., Sciotto, M., Del Bello, E., Scarlato, P., ... Dingwell, D. B. (2017). Timeseries analysis of fissure-fed multi-vent activity: a snapshot from the July 2014 eruption of Etna volcano (Italy). Bulletin of Volcanology, 79(7). doi:10.1007/s00445-017-1132-x

Staudacher, T., Peltier, A., Ferrazzini, V., Di Muro, A., Boissier, P., Catherine, P., ... Lebreton, J. (2016). Fifteen Years of Intense Eruptive Activity (1998-2013) at Piton de la Fournaise Volcano: A Review. In Active Volcanoes of the Southwest Indian Ocean. Active Volcanoes of the World. (pp. 139-170). https://doi.org/10.1007/978-3-642-31395-0_9

Staudacher, T., Ferrazzini, V., Peltier, A., Kowalski, P., Boissier, P., Catherine, P., .. Massin, F. (2009). The April 2007 eruption and the Dolomieu crater collapse, two major events at Piton de la Fournaise (La Réunion Island, Indian Ocean). Journal of Volcanology and Geothermal Research, 184(1-2), 126-137. https://doi.org/10.1016/j.jvolgeores.2008.11.005

Stovall, W. K., Houghton, B. F., Hammer, J. E., Fagents, S. A., \& Swanson, D. A. (2012). Vesiculation of high fountaining Hawaiian eruptions: episodes 15 and 16 of 1959 Kīlauea Iki. Bulletin of Volcanology, 74(2), 441-455. https://doi.org/10.1007/s00445-011-0531-7

Stovall, W. K., Houghton, B. F., Gonnermann, H., Fagents, S. A., \& Swanson, D. A. (2011). Eruption dynamics of Hawaiian-style fountains: the case study of episode 1 of the Kīlauea Iki 1959 eruption. Bulletin of Volcanology, 73(5), 511-529. https://doi.org/10.1007/s00445-010-0426-z

Taddeucci, J., Pompilio, M., \& Scarlato, P. (2004). Conduit processes during the July-August 2001 explosive activity of Mt. Etna (Italy): inferences from glass chemistry and crystal size distribution of ash particles. Journal of Volcanology and Geothermal Research, 137(1-3), 33-54. https://doi.org/10.1016/j.jvolgeores.2004.05.011

Taddeucci, J, Pompilio, M., \& Scarlato, P. (2002). Monitoring the explosive activity of the July-August 2001 eruption of Mt. Etna (Italy) by ash characterization. Geophysical Research Letters, 29(8), 71-1-71-74. https://doi.org/10.1029/2001GL014372 
Thivet, S., Gurioli, L., Di Muro, A., Derrien, A., Ferrazzini, V., Gouhier, M., Coppola, D., Galle, B., Arellano, S. (2020a). Evidences of plug pressurization enhancing magma fragmentation during the September 2016 basaltic eruption at Piton de la Fournaise (La Réunion Island, France). Geochemistry, Geophysics, Geosystems, 21, e2019GC008611. https://doi.org/10.1029/2019GC008611

Thivet, S., Gurioli, L., Di Muro, A. (2020b). Basaltic dyke eruptions at Piton de La Fournaise: characterization of the eruptive products with implications for reservoir conditions, conduit processes and eruptive dynamics. Contribution to Mineralogy and Petrology

Toramaru, A., Noguchi, S., Oyoshihara, S., \& Tsune, A. (2008). MND(microlite number density) water exsolution rate meter. Journal of Volcanology and Geothermal Research, 175(1-2), 156-167. https://doi.org/10.1016/j.jvolgeores.2008.03.035

Toramaru, A. (2006). BND (bubble number density) decompression rate meter for explosive volcanic eruptions. Journal of Volcanology and Geothermal Research, 154(3-4), 303-316. https://doi.org/10.1016/j.jvolgeores.2006.03.027

Urai, M., Geshi, N., \& Staudacher, T. (2007). Size and volume evaluation of the caldera collapse on Piton de la Fournaise volcano during the April 2007 eruption using ASTER stereo imagery. Geophysical Research Letters, 34(22), 1-7. https://doi.org/10.1029/2007GL031551

Velain, C. (1878) Description géologique de la presqu'île d'Aden, de l'île de la Réunion, des îles Saint-Paul et Amsterdam, Hennuyer, Paris, p. 356

Villeneuve, N., \& Bachelery, P. (2006). Revue de la typologie des éruptions au Piton de la Fournaise, processus et risques volcaniques associés. CyberGeo, 2006(January 2016), 1-25.

White, J. D. L., \& Houghton, B. F. (2006). Primary volcaniclastic rocks. Geology, 34(8), 677. https://doi.org/10.1130/G22346.1

Wilson, T. M., Jenkins, S., \& Stewart, C. (2015). Impacts from Volcanic Ash Fall. In Volcanic Hazards, Risks and Disasters (pp. 47-86). Elsevier. https://doi.org/10.1016/B978-0-12-396453-3.00003-4

Zimanowski, B., Büttner, R., Dellino, P., White, J. D. L., \& Wohletz, K. H. (2015). Magma-Water Interaction and Phreatomagmatic Fragmentation. The Encyclopedia of Volcanoes, 473-484. https://doi.org/10.1016/b978$0-12-385938-9.00026-2$ 